\title{
Update on lyssaviruses and rabies: will past progress play as prologue in the near term towards future elimination?
}

\author{
Rodney E. Rohde ${ }^{1}$ Charles E. Rupprecht ${ }^{2 *}$ \\ ${ }^{1}$ Clinical Laboratory Science, Texas State University, San Marcos, TX, 78666, USA \\ ${ }^{2}$ LYSSA LLC, Cumming, Georgia, 30004, USA
}

\begin{abstract}
Rabies is an ancient, much-feared, and neglected infectious disease. Caused by pathogens in the family Rhabdoviridae, genus Lyssavirus, and distributed globally, this viral zoonosis results in tens of thousands of human fatalities and millions of exposures annually. All mammals are believed susceptible, but only certain taxa act as reservoirs. Dependence upon direct routing to, replication within, and passage from the central nervous system serves as a basic viral strategy for perpetuation. By a combination of stealth and subversion, lyssaviruses are quintessential neurotropic agents and cause an acute, progressive encephalitis. No treatment exists, so prevention is the key. Although not a disease considered for eradication, something of a modern rebirth has been occurring within the field as of late with regard to detection, prevention, and management as well as applied research. For example, within the past decade, new lyssaviruses have been characterized; sensitive and specific diagnostics have been optimized; pure, potent, safe, and efficacious human biologics have improved human prophylaxis; regional efforts have controlled canine rabies by mass immunization; wildlife rabies has been controlled by oral rabies vaccination over large geographic areas in Europe and North America; and debate has resumed over the controversial topic of therapy. Based upon such progress to date, there are certain expectations for the next 10 years. These include pathogen discovery, to uncover additional lyssaviruses in the Old World; laboratory-based surveillance enhancement by simplified, rapid testing; anti-viral drug appearance, based upon an improved appreciation of viral pathobiology and host response; and improvements to canine rabies elimination regionally throughout Africa, Asia, and the Americas by application of the best technical, organizational, economic, and socio-political practices. Significantly, anticipated Gavi support will enable improved access of human rabies vaccines in lesser developed countries at a national level, with integrated bite management, dose-sparing regimens, and a 1 week vaccination schedule.
\end{abstract}

\section{Keywords}

Disease, Elimination, Encephalitis, Lyssavirus, Rabies, Vaccine, Virus, Zoonosis, Rabies

\section{Peer Review}

The peer reviewers who approve this article are:

1. Gyanendra Gongal, Regional Focal Point for Rabies, World Health Organization, Regional Office for South-East Asia, New Delhi, India

Competing interests: No competing interests were disclosed.

2. Stefan Finke, Institute of Molecular Virology and Cell Biology, Friedrich-Loeffler-Institut, Greifswald, Insel Riems, Germany

Competing interests: No competing interests were disclosed. 
*Corresponding author: Charles E. Rupprecht (charleserupprechtii@gmail.com)

Competing interests: The authors declare that they have no competing interests.

Grant information: The authors declare that no grants were involved in supporting this work.

Copyright: $\odot 2020$ Rupprecht CE et al. This is an open access article distributed under the terms of the Creative Commons Attribution License, which permits unrestricted use, distribution, and reproduction in any medium, provided the original work is properly cited.

How to cite this article: Rohde RE and Rupprecht CE. Update on lyssaviruses and rabies: will past progress play as prologue in the near term towards future elimination? Faculty Reviews 2020 9:(9) https://doi.org/10.12703/b/9-9

Published: 16 Nov 2020, Faculty Reviews 9:(9) https://doi.org/10.12703/b/9-9 


\section{Introduction}

As reflected by the recent emergence of the novel coronavirus, SARS-CoV-2, such pathogens continue to pose substantial yet somewhat predictable concerns to human health and welfare at a global level. In contrast to more newly appreciated threats, rabies is one of the oldest described infectious diseases, likely with a more ancient pedigree, pre-dating most historical accounts ${ }^{1}$. Rabies and related lyssaviruses continue to cause major mortality in countless mammalian species, including Homo sapiens, domestic animals, and wildlife ${ }^{2}$. Although lyssavirus-related mortalities remain uncommon in humans within developed countries, these viruses, and the burden posed in lesser developed countries (LDCs), have captured the attention of scientific, agricultural, and public health communities because of their extreme fatality rate, the highest for any conventional agents, with an estimated human death every 10-15 minutes ${ }^{3}$. Having the capacity to cause severe disease with serious health and economic implications, without efficient treatment yet available, rabies is considered a major neglected viral zoonosis. As a vaccine-preventable disease, the Food and Agriculture Organization (FAO), the World Organization for Animal Health (OIE), and the World Health Organization (WHO) have focused upon an ambitious plan for the global elimination of human rabies mediated via dogs (GEHRD) or 'Zero by Thirty' (ZBT) by 2030 (https://www.who.int/news-room/detail/28-092019-united-against-rabies-collaboration-celebrates-one-year-ofprogress-towards-zero-human-rabies-deaths-by-2030). This plan was perhaps the singular galvanizing event of the early $21^{\text {st }}$ century, in a sea of other notable examples over the past 10 years, that has reset the underpinnings for challenges and success in the field, as currently appreciated ${ }^{4-19}$ (Table 1). The objective of this brief commentary is to provide an update on the recent progress and extant dilemmas related to rabies and to highlight evidence-based opinions on the evolving scenarios forecast to arise over the next "ZBT decade", illustrated objectively by data provided through the contemporary, peer-reviewed literature, exemplified primarily during the last few years ${ }^{1-201}$.

\section{Viral characteristics}

Taxonomically, the etiological agents reside in the order Mononegavirales, family Rhabdovirus, genus Lyssavirus. Rabies virus is the type-species and most important member of this mono-phyletic genus. Since the 1950s, at least 17 other recognized and proposed lyssavirus species have been described from Africa, Australia, and Eurasia, all of which can be differentiated antigenically and genetically yet cause a clinically indistinguishable encephalitis and not a so-called 'rabies-like' disease (https://talk.ictvonline.org/ictv-reports/ictv_online_report/negative-sense-rna-viruses/mononegavirales/w/rhabdoviridae/795/ genus-lyssavirus).

The basic viral structure consists of a characteristic bullet-shape and helical symmetry by transmission electron microscopy (https://apps.who.int/iris/bitstream/handle/10665/310836/ 9789241515153-eng.pdf?ua=1). Ultrastructurally, lyssaviruses may be distinguished from other rhabdoviruses, but not from one another. Virions have a length of about $180 \mathrm{~nm}$ (130-300 nm) and a diameter ranging from 45 to $100 \mathrm{~nm}$

Table 1. Highly notable events in the applied rabies field related to detection, prevention, and control over the past decade.

\begin{tabular}{|l|l|}
\hline Item & Reference \\
\hline Discovery of new lyssavirus species & 4 \\
\hline Suggestion of rabies virus adaptation beyond carnivores and bats to other mammals, such as non-human primates & 5 \\
\hline Greater appreciation of wildlife reservoirs in previously considered "rabies-free" areas & 6 \\
\hline $\begin{array}{l}\text { Recognition of additional antigen detection, serological, and molecular tests for very sensitive and specific } \\
\text { lyssavirus diagnosis }\end{array}$ & 7 \\
\hline Recognizable shifts from animal culling to mass dog vaccination as a proven management strategy & 8 \\
\hline Planning for the global elimination of human rabies mediated via dogs by 2030 & 9 \\
\hline Greater focus upon local infiltration of wounds with scarce rabies immunoglobulins & 10 \\
\hline Availability of human monoclonal antibodies as an alternative to polyclonal rabies immunoglobulin & 11 \\
\hline Recommendations on dose-sparing and shorter 1 week human prophylaxis regimens & 12 \\
\hline Expansion of the distribution of vampire bats and rabies virus spread & 13,197 \\
\hline $\begin{array}{l}\text { Support for pre-exposure vaccination for those in remote settings, such as children in communities with a high } \\
\text { exposure rate to canine rabies virus and those at risk of vampire bat depredation }\end{array}$ & 14 \\
\hline In vitro alternatives to animal testing in the determination of vaccine potency & 15 \\
\hline Demonstration of compounds with repeatable in vitro anti-rabies virus activity & 16 \\
\hline Renewal of interest for the oral vaccination of free-ranging dogs against rabies & 17 \\
\hline Elimination of canine rabies in Mexico & 18 \\
\hline Expectations of Gavi support for human rabies vaccination & 19 \\
\hline
\end{tabular}


(with one rounded and a flattened end). The bacilliform or rod-like particles appear hemi-spherical at both ends when mature. Lyssavirus plane projection imagery reveals surface spicules, a host cell-derived envelope, and a nucleocapsid with helical symmetry. This thin fringe of spicules, about $8 \mathrm{~nm}$ thick, does not cover the surface of the plane end of the virus. The genome, approximately $12 \mathrm{~kb}$ in size, is composed of a negative-sense, single-stranded, non-segmented RNA and contains five transcription units encoding five viral structural proteins (3'-N-P-M-G-L-5'), separated by short noncoding introns, except for a longer, noncoding intergenic G-L region (https://apps.who. int/iris/bitstream/handle/10665/310837/9789241515306-eng. pdf?ua=1). The viral structural proteins include the nucleoprotein $(\mathrm{N}, \sim 400 \mathrm{aa})$, the phosphoprotein $(\mathrm{P}, \sim 300 \mathrm{aa}$, as a cofactor of the polymerase), the matrix protein (M, 200 aa), the outer surface glycoprotein ( $\mathrm{G}, \sim 500$ aa), and the RNA-dependent RNA polymerase ( $\mathrm{L}, \sim 2,000$ aa). Besides their classically recognized role in structure, receptor binding, membrane fusion, endosome formation, uncoating, encapsidation, transcription, translation, replication, assembly, and release, the viral proteins are also involved in subtle immune evasion and overt disease progression ${ }^{20,21}$. Improving upon much earlier ultrastructural accounts, recent studies using high-resolution imaging, cryoelectron microscopy, crystal structural and functional analyses, proteomic profiling, and molecular modeling have provided unique insights into a finer understanding of dynamic viral and host protein interactions, neurotropism, the underlying regulation of replication and transcription, intracellular transport, and the future development of more rapid diagnostics, novel biologics, and rational anti-viral drug design ${ }^{22-32}$.

\section{Pathogenesis}

In a rabid animal, virions are shed intermittently in the saliva, usually transmitted via a bite and deposited deeply within a wound, eventually access the peripheral nervous system, travel in retrograde fashion, replicate primarily in the central nervous system, and transit gradually to the salivary glands and other tissues, in a well-known, generalizable productive infectious cycle model ${ }^{33}$. Lyssaviruses display a high degree of neurotropism, with a preference for neurons, but non-neuronal cells may also be targeted ${ }^{34}$. For entry, the viral $G$ protein can recognize not just one but several host cell receptors that are highly conserved among a diversity of avian, marsupial, and placental species, albeit at apparently different relative efficiencies and outcomes. For example, the wide-ranging ability to infect neuronal, muscle, and epithelial cells and fibroblasts suggests a rather ubiquitous expression of entry receptors in different tissues $^{33}$. In contrast to some other rhabdoviruses, lyssaviruses are not lymphotropic. Besides neurons, some lyssaviruses can infect specialized neuro-epithelial cells ${ }^{35}$. Nevertheless, viral dissemination within the infected host is facilitated primarily via attachment to, transport by, and replication within neurons ${ }^{33}$. As a quintessential neurotropic pathogen, rabies virus continues to be used experimentally as an anatomical transneuronal tracer, to better understand connectivity within the nervous system ${ }^{189}$.

Viral replication and assembly occur in compartmentalized, sequestered intracytoplasmic "factories", historically termed
Negri bodies, a histopathological hallmark of infection for over a century, although not always detected readily, which limited their diagnostic utility in the face of improved tests ${ }^{29}$. Despite the virulence of rabies, gross and microscopic injuries may appear rather minor and principle pathogenic mechanisms remain unclear. For example, lyssavirus infection of neurons may result in mitochondrial dysfunction, producing oxidative stress and acute degenerative changes of neuronal processes ${ }^{36}$. In addition, one potential host-mediated response implicates a role for the $S A R M 1$ gene in axonal "self-destruction", impeding viral spread but also with subsequent pathological impacts of neuronal and dendritic cell loss ${ }^{37}$.

Operationally, exposure is defined as transdermal or mucosal contamination with saliva, brain tissue, or other virus-containing substances $^{2}$. Human cases continue to be documented following exposure via these well-recognized routes ${ }^{38-40}$. Incubation periods range from less than a week to greater than a year (i.e. typically shorter, after bites to the head and neck), with most cases presenting within 4-6 weeks of exposure ${ }^{41}$. The few documented occurrences of exceptionally long incubation periods (i.e. exceeding several years) remain poorly understood regarding mechanism, localization, recognition, etc., or whether much delayed prophylaxis would be effective after the initial infection process $^{2}$. Initial illness is characterized by non-specific onset, including fever, headache, dizziness, vomiting, and myalgia. Later, subjects may experience severe encephalitis, including hydrophobia, aerophobia, and photophobia. Patients succumb from cardio-pulmonary dysfunction and complications related to multiple organ failure ${ }^{42}$. Delayed innate immune responses may contribute to pathology $y^{43}$. The very few survivors from infection frequently have long-term neurological sequelae $e^{44,190}$. Clinical suspicion is heightened after documentation of rabid animal exposure and the onset of compatible signs, but conflicts in adequate laboratory confirmation may confound interpretations ${ }^{45}$.

\section{Immune responses}

Innate immunity plays a critical first-line role in anti-viral host defense and modulation of infection after lyssavirus exposure. Toll-like receptors (TLRs), cytoplasmic ds-RNA, and triphosphate-RNA sensors (among others) are part of the host pattern recognition system, activated after sensing of viral RNA post-infection $^{186,187}$. Activation of TLR3, TLR7, etc., results in a cascade of events, including the production of interferons (IFNs) and interleukins and the induction of initial adaptive immune responses, including the recruitment of $\mathrm{B}$ cells and facilitation of germinal center formation ${ }^{46}$. If, after inoculation into a peripheral lesion, local lyssavirus infection is followed by the production of viral RNA, sensed by TLRs and other pathways, leading to the activation of IFN-stimulated genes, induction of IFN, and the incitement of subsequent anti-viral signaling, then how does a productive infection actually ensue? Suppression of anti-viral defense signals, such as for IFN production, could lead to a promotion of viral spread by disrupting both innate and adaptive immunity. Several mechanisms have been described in which viral structural proteins were found to be involved in the blocking of cytokine signaling pathways ${ }^{47}$. In addition, 
lyssaviruses may restrict $G$ protein expression and reduce its incorporation into mature virions, subverting the activation of antigen-presenting dendritic cells ${ }^{48}$. Such mechanisms constitute a combined viral immune evasion and suppression strategy, supporting overall a more efficient host invasion. Although somewhat ignored, immunity as defined by the induction of virus-neutralizing antibodies (VNAs) against lyssaviruses can be operative and protective in naïve (i.e. unvaccinated human or other animal) hosts ${ }^{49}$. Administration of attenuated, recombinant, and adjuvanted veterinary biologics or high-potency, multi-dose, prime-boosting applications of inactivated human vaccines promote both innate and humoral immunity via antigen-presenting cells, T cell differentiation, the induction of VNA-secreting plasma cells, and long-lived memory B cells ${ }^{50}$.

\section{Diagnostic applications}

Often overlooked, rabies diagnosis has undergone a seeming renaissance of late $e^{2,751-53}$. Infection is confirmed by the finding of viral antigens, antibodies, amplicons, nucleic acids, or biomarkers in subjects with signs compatible with an encephalitis. When a case of rabies is suspected, management decisions are made that run the gamut from an individual, exposed patient to a programmatic intervention ${ }^{54}$. Hence, laboratory evaluation is critical. Although most testing occurs postmortem in animals, the diagnosis of rabies in humans prior to death (i.e. antemortem) provides definitive diagnosis for infection control, closure for families, identification of others who may have been exposed to the same source, appropriate patient palliation or rare hope, and the opportunity to attempt experimental therapeutic approaches ${ }^{55}$. Prior traditional methods for antemortem and postmortem rabies diagnosis had multiple limitations. Advances in "best fit" technology and understanding of basic viral pathobiology have led to the improvement or design of many more diagnostic options, beyond the $20^{\text {th }}$ century detection of Negri bodies. Such newer assays, augmented by traditional methods, have begun to revolutionize lyssavirus diagnosis across the global landscape. Unfortunately, while there are antemortem methods for confirmation concomitant with encephalitis, there are still no sensible diagnostic tests available for lyssavirus detection prior to onset of clinical disease. Moreover, assay choice, sample selection, protocol adherence, and post-analytical interpretation issues are not unique to lyssavirus diagnostic challenges, as described in detail in the latest WHO monograph of laboratory methods ${ }^{7}$.

Historically, conventional testing included (1) direct microscopic detection of intracytoplasmic inclusions (i.e. Negri bodies) in infected neurons (no longer recommended for routine primary diagnosis); (2) direct fluorescent microscopy (direct fluorescent antibody [DFA]) during postmortem diagnosis (i.e. widely used in animals and humans as a standard test), with direct staining of viral antigens in touch impressions of brain tissues, including portions of the brainstem (i.e. needed for a definitive diagnosis), the cerebellum, or the hippocampus; (3) virus isolation (i.e. usually reserved in research settings or for confirmatory diagnosis when the DFA test gives a weak or uncertain result) with two primary tests being the mouse inoculation test and the rapid tissue culture infection test in MNA cells;
(4) rapid rabies enzyme immune diagnosis, an enzyme-linked immunosorbent assay (ELISA)-based technique which detects the viral $\mathrm{N}$ antigen; (5) antibody demonstration in the serum (in the absence of a history of vaccination) or in CSF, offering indirect evidence of infection by demonstration of anti- $\mathrm{N}$ antibodies or anti-G VNA (i.e. via virus neutralization), including the mouse neutralization test (no longer recommended), the rapid fluorescent focus inhibition test (RFFIT), and the fluorescent antibody virus neutralization test (FAVN).

Over the past decade, a variety of molecular methods, many based on PCR modalities, are increasingly applied to various sample types for human antemortem diagnosis and as a confirmatory test for other samples ${ }^{7}$. Likewise, immunohistochemical methods traditionally applied for rabies diagnosis of fixed, paraffin-embedded tissues are now being leveraged as tools explore for more rapid applications. These tests, many now automated, include (1) the direct rapid immunohistochemical test (dRIT), which is an approximately 1 hour test based on detecting viral $\mathrm{N}$ protein in brain tissue; (2) the indirect rapid immunohistochemistry test (iRIT), offering the detection and differentiation of virus variants via traditional light microscopy; (3) the reverse transcriptase polymerase chain reaction (RT-PCR) assay, the most frequently employed molecular method that seeks to detect rabies virus and related lyssavirus RNA; (4) the qPCR-based assays (with varying chemistry and detection kits), allowing for the "real-time" detection and quantification of genome copies, with the advantage of a closed-tube assay for a significant reduction in cross contamination; (5) the Qiagen QIAsymphony $\mathrm{SP} / \mathrm{AS}$, in conjunction with quantitative reverse transcription-PCR (qRTPCR); (6) the rapid immunodiagnostic test (RIDT), detecting antigens from postmortem samples and utilized without the need for more sophisticated laboratory equipment, which is based on a lateral flow strip assay in a one-step test that facilitates low-cost, rapid identification of viral antigens; (7) nucleic acid sequence-based amplification (NASBA), which allows the utilization of three enzymes to produce multiple copies of RNA in isothermal conditions; (8) and several other updated assays (e.g. Platelia Rabies II ELISA, a rapid antibody detection test (RAPINA) based on immunochromatography, latex agglutination tests for rabies virus-specific antibodies, proteomics, metabolomics, etc.). These provide multiple options for laboratorians in both developed countries and LDCs.

One additional method, the LN34 pan-lyssavirus RT-PCR assay, represents an idealized candidate test for postmortem diagnostics, owing to its ability to detect RNA across the diversity of the viral genus, high sensitivity, potential for use with deteriorated tissues, and user-friendly design ${ }^{56}$. Providing data from a multi-site evaluation of the LN34 assay in 14 laboratories using 2,978 samples (1,049 DFA-positive) from Africa, the Americas, Eurasia, and the Middle East, high diagnostic specificity (i.e. 99.7\%) and sensitivity (i.e. 99.9\%) were shown when compared to the DFA test (i.e. no DFA-positive samples were negative by the LN34). The LN34 assay exhibited low variability in repeatability and reproducibility studies, suggesting a new gold standard for centralized laboratories. Once quality control is optimized, utilization of more directed, improved point-of-care diagnostics 
should range from enhanced surveillance activities in the field to better assessment of exposed patients in the clinic under more real-time conditions in support of better understanding of the underlying disease epidemiology for timely responses s, $^{2,57,58}$.

\section{Epizootiological insights}

As a representative disease of nature, any presumption that rabies is "rare" is a simple fallacy, dependent upon epidemiolocal context and the public/professional reference frame (http:// outbreaknewstoday.com/rabies-signs-and-symptoms-exposuretransmission-and-diagnostics-81094/). As lyssaviruses are RNA viruses, an expectation of reasonably high mutation rates in the face of strong purifying selection is the rule for anticipated fixation, adaptation, emergence, and extinctions in the short term and over longer historical periods. Lyssaviruses exist as "ecological ensembles", metapopulations of distinct species and variants, residing within multi-reservoir mammalian communities in often rapidly changing environments ${ }^{59}$. Such host population-viral assemblages are perpetuated in ecologically diverse urban, rural, and wilderness ecosystems, from the Tropics to the Arctic ${ }^{60-64}$. Despite this broad host spectrum and wide geographic distribution, from a public health perspective, based upon laboratory-based surveillance and epidemiological analyses, today the overwhelming number of human fatalities are still due to rabid domestic dogs, primarily in $\mathrm{LDCs}^{65,66}$. By comparison, transmission to humans by rabid wildlife, in both developed countries and LDCs, is much less common ${ }^{67-76}$ (Table 2).

Evolutionarily, bats are recognized as the ultimate reservoir of the lyssaviruses ${ }^{1,2,77}$. Despite more than 17 conspecific members, rabies virus appears to be the only lyssavirus with clear reservoir representation among multiple orders of mammals 1,2,78 $^{1}$. Unique to the region, independent rabies virus lineages may be found among multiple bat species throughout the Americas ${ }^{64,79-81}$. Host shifts from engagement of bat rabies viruses to other mammals are suggested by derived variants in raccoons, skunks,

Table 2. Documented examples of recent reports of human rabies cases transmitted by wildlife.

\begin{tabular}{|l|l|l|}
\hline Mammal & Locality & Reference \\
\hline Insectivorous bat & USA & 67 \\
\hline Vampire bats & Latin America & 68 \\
\hline Wolf & Russian Federation & 69 \\
\hline Fox & China & 70 \\
\hline Jackals & Bangladesh & 41 \\
\hline Raccoon dogs & South Korea & 71 \\
\hline Ferret badgers & China & 72 \\
\hline Skunk & Mexico & 73 \\
\hline Raccoon (or spillover to cat?) & USA & 74 \\
\hline Mongoose & Puerto Rico & 75 \\
\hline Non-human primates & India & 76 \\
\hline
\end{tabular}

and marmosets in the New World ${ }^{1,2,5,82,83}$. Additionally, multiple mesocarnivore variants (much more distantly descended originally from ancestral bat rabies viruses) are now represented by dogs, other wild canids, mustelids, mongoose, etc. in both the Old and the New Worlds ${ }^{84}$. Although most rabies virus variant transmission patterns are intrinsically intraspecific (e.g. dog-to-dog, bat-to-bat, etc.), interspecific spillover infection may occur to practically any bitten mammal, from a veritable alphabet soup of armadillos to zebras ${ }^{85}$. While some spillovers may be amplified by short transmission chains, the majority of these are ultimately dead-end infections, such as to domestic or wild hoofed stock. Perhaps the most extreme example of the latter is the case of dog-jackal-kudu rabies in southern Africa $^{86}$. Transmission of rabies viruses from domestic animals or wildlife to humans is almost always a single term event (i.e. the person dies without a secondary case), except for the rarity of human-to-human infection from tissue/organ transplants ${ }^{87}$. Such instances are examples of the devastating amplifying consequences when rabies is unsuspected, ignored, or mis-diagnosed.

Early to end-stage clinical manifestations of encephalitis are generally recognized as key supportive factors in viral transmission, along the lines of mania ${ }^{88}$. However, even "normal", daily social behaviors, involving mucosal or transdermal exposures, may also be operative towards routine perpetuation, as viral excretion in the saliva occurs days before the onset of abnormal signs. Morphologically, mammalian heterodont teeth have several different shapes and multiple functions, to bite, rip, grind, crush, groom, nip, shear, stab, suckle, etc. Beyond primary use in prey capture, killing, and feeding or for established specialized behaviors, the effectiveness of mammalian transmission of lyssaviruses via a bite may be better appreciated by cursorial examination of such teeth from a representative canid (Figure 1A), felid (Figure 1B), vampire bat (Figure 1C), and insectivorous bat (Figure 1D), designed for many different functions but secondarily repurposed as highly effective "pathogen delivery devices" into peripheral tissues. This feature is enhanced by inter-related characteristics, such as local muscular strength, bite force, physical dexterity, chewing capacities, etc., as basic life history attributes of most predators, in stark contrast to the feeding apparatus of a typical mammalian herbivore (Figure 1E). Such ultimate outcomes for highly successful intraspecific viral perpetuation appear obvious (e.g. rabid fox to fox, raccoon to raccoon, bat to bat, etc.), as well as for spillover opportunities to different species (e.g. rabid fox to deer, raccoon to woodchuck, bat to cow, etc.), with relevant public health, agricultural, and environmental ramifications ${ }^{89-91}$. For example, some of the highest case fatalities have occurred after human exposure to rabid wolves (likely infected originally by interactions with rabid dogs), given the risk for severe cranio-facial bites ${ }^{92}$. Also, while felids do not serve as typical reservoirs, they are highly efficient predators/vectors, presumably infected primarily during aggressive encounters with a bat, or via another mesocarnivore, such as a rabid dog, fox, raccoon, skunk, mongoose, ferret badger, etc., before a human or other species encounter ${ }^{93}$. In contrast to carnivores, vampire bats, as obligate vertebrate parasites, are the only mammals involved in natural viral exposures 


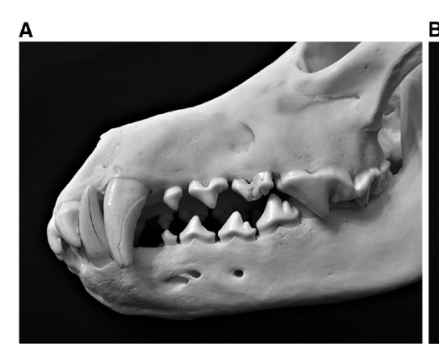

C
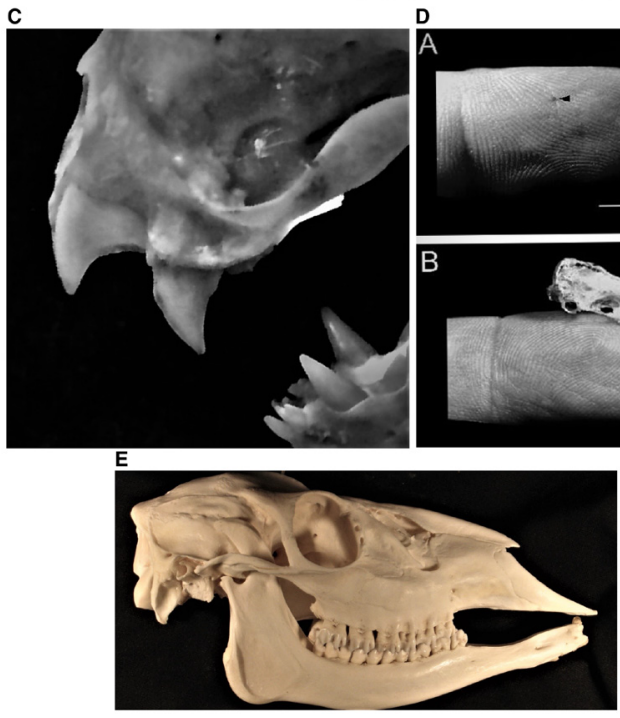

Figure 1. Lyssavirus virions are effectively transmitted transdermally via the saliva into peripheral tissues of a prospective host by the bites of infected mammals, as exemplified by representative mesocarnivores and bats (and in contrast to herbivores). 1A. Close-up of the canines and carnassial teeth of a canid apex predator, the North American gray wolf, Canis lupus. 1B. Close up of the canines and carnassial teeth of the most common rabid wild felid diagnosed within North America, the bobcat, Lynx rufus. 1C. Close up of the specialized incisors and canines of the common vampire bat, Desmodus rotundus. 1D. Example of an insectivorous bat bite. A. Demonstration of a typical small lesion to a finger from an insectivorous bat (bar inset approximately $1 \mathrm{~cm}$ ). B. Comparison of the skull of an insectivorous bat to a human digit. This figure was reprinted with permission from Elsevier (Jackson AC, Fenton MB. Human rabies and bat bites. The Lancet. 2001. 357:1714201. 1E. Lateral view of the skull of a representative mammalian herbivore, demonstrating the distinct operational differences in the dentition (i.e. incisors, canines, and cheek teeth) between those taxa serving largely as "dead-end rabies victims" in contrast to typical lyssavirus reservoirs and vectors, depicted in 1A-D (This figure was adapted from Smalette, specimen 12092010, Wikimedia Commons, the free media repository, licensed under the terms of Creative Commons Attribution-Share Alike 3.0 Unported license https://commons. wikimedia.org/wiki/File:12092010_Right_View.JPG\#filelinks).

to other taxa directly because of their hematophagous nature, due to preying upon much larger livestock, humans, or other mammals ${ }^{94}$. For nearly all other, non-vampire bat-human encounters, individuals may not receive prophylaxis because of ignorance of the risk or because they may not realize they were exposed $^{95}$. Although human infections with bat lyssaviruses have been documented on all continents, outside the Americas and Europe, this risk may not be appreciated more widely in Africa and Asia, where few human cases receive laboratory confirmation or characterization and the current epidemiological introspection is well focused upon the task of canine rabies remediation $1,2,4,77$

Fundamentally, as nearly all rabies cases occur after a bite, applied epidemiological data collection on the incidence of animal bite by age, sex, season, locality, species, etc., can be highly informative to public health policy creation in mitigating risks of disease occurrence by preventing and responding to exposures $2,41,58,74,86,91,92,95,191$. Applied appropriately with mass dog vaccination and human prophylaxis in a local, national, or regional One Health context saves lives and healthcare costs ${ }^{2,96}$. For example, one multi-variate regression study in seven Latin American countries from 1995-2005 found that an increase in dog vaccinations decreased canine rabies cases, reported human exposures, and human deaths ${ }^{8}$. Within the Middle East, research incorporating proven epidemiological methods with phylogeographic approaches has shown the impact of environmental factors upon canine rabies virus dispersal ${ }^{97}$. Such anthropogenic facets have undoubtedly played a critical part since canine domestication to the present, given historical interdependence, translocations, and close animal-human bonds ${ }^{1,2,84}$. This increasing integration of classical epidemiological methodology with modern diagnostics, molecular techniques, health economics, or modeling approaches has provided key insights into applied rabies dynamics, improved prophylaxis, cost-effective prevention, and multi-species control strategies ${ }^{2,59,98-110}$ (Table 3).

\section{Modern strategies to prevent, control, and selectively eliminate rabies}

Before the $20^{\text {th }}$ century, most global rabies prevention and control efforts focused upon a gamut of responses, including denial, avoiding exposures, quackery, quarantine, isolation, dog killing, collaring or muzzling, and wildlife culling, with varying levels of success. Thereafter, although some of these earlier strategies are still employed, a century of development has now resulted in pure, potent, safe, and effective rabies vaccines for administration to humans, domestic animals, and wildlife $\mathrm{e}^{2,111-113}$. Somewhat unique for viral diseases, these vaccines may be used routinely for either pre-exposure prophylaxis (PrEP) or postexposure prophylaxis (PEP) to minimize the opportunity for a productive lyssavirus infection (Table 4). Updated recommendations for human prophylaxis have been forthcoming, built upon epidemiological insights and clinical studies of biologics first licensed during the latter part of the $20^{\text {th }}$ century, focused upon greater dose-sparing use of the intradermal route of vaccine administration, shorter regimens, infiltration of rabies immunoglobulins (RIGs) or monoclonal antibodies, and relevant applications of PrEP to those at risk $^{2,10-12,14,19,98,114}$. Greater harmonization of these guidelines is expected to follow suit in both LDCs and developed countries ${ }^{115}$. Unfortunately, despite highly effective PrEP and PEP, humans will still succumb to rabies because they receive no prophylaxis, a lack of RIGs or infiltration, inadequate vaccination, or a delay in PEP of several days or more, especially after a severe exposure. Historical 
Table 3. Selective illustration of a diversity of recent epidemiological applications in humans, domestic animals, and wildlife for improved detection, prevention, and control on a global basis.

\begin{tabular}{|l|l|}
\hline Example & Citations \\
\hline Informatics for policy making on human prophylaxis recommendations at a global level & 98 \\
\hline Predictive modeling of potential spatial spread in a canine rabies-free continent & 99 \\
\hline Annual animal rabies laboratory-based surveillance summary for North America & 74 \\
\hline Emergency department syndrome-based surveillance & 100 \\
\hline Meta-analysis of animal bite statistics in Iran & 92 \\
\hline Using ecological insights to overcome barriers for improved canine vaccination & 101 \\
\hline Geographic information system use for wildlife rabies outbreak response & 102 \\
\hline Health economics comparison of canine rabies control demonstration sites in Africa and Asia & 103 \\
\hline Public health investigation of mass human exposure events from bats in the USA & 104 \\
\hline Cohort assessment of the risk of rabies in biting Haitian dogs & 105 \\
\hline Retrospective, multi-hospital analysis of the relative adequacy of rabies immunoglobulin administration to patients & 106 \\
\hline Prospective, spatiotemporal study of human exposure risk factors in Ethiopia & 107 \\
\hline $\begin{array}{l}\text { Cross-sectional household survey on dog populations, bite incidence, and rabies knowledge in an African community } \\
\text { at risk }\end{array}$ & 108 \\
\hline Case series of rare human rabies survivors in India & 109 \\
\hline $\begin{array}{l}\text { Human case report, after substantial patient contact with bats in the home, but without prophylaxis, demonstrating } \\
\text { the need for continued education }\end{array}$ & 110 \\
\hline
\end{tabular}

Table 4. Use of prophylaxis before or after lyssavirus exposure in humans, domestic animals, and wildlife ${ }^{2,11,112}$.

\begin{tabular}{|l|l|l|}
\hline Group & Pre-exposure prophylaxis & Post-exposure prophylaxis \\
\hline Humans & $\begin{array}{l}\text { Parenteral vaccine doses administered to any persons at } \\
\text { risk of viral exposure, with serological surveillance of certain } \\
\text { occupational groups (i.e. laboratory workers, veterinarians, etc.) } \\
\text { for determination of a routine booster when immunity wanes, } \\
\text { based upon virus neutralization antibody detection }\end{array}$ & $\begin{array}{l}\text { Thorough wound cleansing, infiltration of rabies } \\
\text { immunoglobulin into wounds, and parenteral } \\
\text { administration of several doses of rabies vaccine (for the } \\
\text { previously vaccinated person, only rabies vaccine is } \\
\text { administered) }\end{array}$ \\
\hline $\begin{array}{l}\text { Domestic } \\
\text { animals }\end{array}$ & $\begin{array}{l}\text { Ideally, all domestic animals (but especially dogs and cats) at risk } \\
\text { of exposure should receive a single parenteral vaccine at around } \\
\text { 3 months of age, a booster at about 1 year of age, and periodic } \\
\text { annual or triennial boosters dependent upon label indications and } \\
\text { local regulations }\end{array}$ & $\begin{array}{l}\text { Immediate, single, parenteral re-vaccination upon known } \\
\text { exposure to invoke an anamnestic response }\end{array}$ \\
\hline Wildlife & $\begin{array}{l}\text { Mesocarnivore reservoirs (e.g. coyotes, ferret badgers, foxes, } \\
\text { jackals, mongoose, raccoons, raccoon dogs, etc.) may be } \\
\text { targeted for oral vaccination by well-designed programs for which } \\
\text { vaccine safety and efficacy have been determined (in addition, } \\
\text { parenteral vaccination may occur for mammals maintained in } \\
\text { zoological collections or by trap-vaccinate-release of free-ranging } \\
\text { wild mammals) }\end{array}$ & $\begin{array}{l}\text { Primarily occurs naturally when a previously vaccinated } \\
\text { animal develops an anamnestic response upon } \\
\text { consumption of another dose of oral vaccine }\end{array}$ \\
\hline
\end{tabular}

and recent work highlights the importance of humoral immune responses and the role of VNAs directed against the viral $G$ protein $^{113}$. Although the development of new biologics is ongoing and the scrutiny to obtain vaccines directed against disparate lyssaviruses continues, the only approved products on the market are directed against rabies virus. Several new vaccine development concepts have been studied in animal models, including novel adjuvants, virus-like particles, and nucleic acid-, chimeric rabies virus-, simian adenovirus-, and epitope-based vaccines ${ }^{50,192,193}$. These approaches could expand the spectrum of coverage and may require even fewer vaccine doses or less-expensive applications for either human PrEP or PEP. Regardless of future innovations, rabies virus is the predominant lyssavirus of importance. As such, human survival is virtually assured by the prompt and proper use of today's biologics after rabies virus exposure. 
Equally impressive to the progress in the use of human prophylaxis is the success also demonstrated for animals ${ }^{116-124}$ (Table 5). All developed countries eliminated canine rabies. Increasingly, LDCs repeated the model, starting with the regional program in the Latin American countries, despite large numbers of free-ranging dogs in urban centers and rural communities. While the GEHRD can be accomplished via the combination of human prophylaxis and domestic animal control by vaccination, without the elimination of canine rabies virus circulation, the longterm effectiveness of such a strategy equates to the "incurable wound". Rather, by removing the underlying problem, a primary rationale for most of the more-costly human prophylaxis is minimized. Such a vision is feasible, as the accumulated data from disease modeling studies indicate that the basic reproduction number, $\mathrm{R}_{0}$, is less than 2 , control through mass canine vaccination is highly effective in reducing cases in dogs and subsequently in humans owing to a reduced animal burden, and $\sim 70 \%$ annual coverage is a sound target for prevention ${ }^{125,126}$. Concerns about the estimated population of dogs to vaccinate, actual determination of vaccine coverage, relative density, age and birth rates, levels needed to prevent re-establishment from endemic areas, and more efficient methods of reaching free-ranging animals are identified as some of the crucial factors influencing the effectiveness of such interventions ${ }^{125-128,194}$.

Beyond prevention in humans and domestic animals, rabies is the only zoonosis in which wildlife vaccination, using attenuated or recombinant biologics, has risen from an academic concept to a safe, effective, and economical long-term practice on a grand scale ${ }^{129-133}$. For example, after the multi-year use of oral rabies vaccine (ORV) distributed in edible baits, western Europe and large parts of southern Ontario became free of fox rabies $^{124,134}$. Within the Republic of Korea, ORV was used for the elimination of rabies virus in raccoon $\operatorname{dogs}^{132}$. In the USA, ORV for raccoons began during 1990 and programs to date have prevented raccoon rabies spread beyond the eastern states as plans are formulated for elimination ${ }^{135}$. Locally, within the state of Texas, large outbreaks in coyotes and gray foxes occurred during the late 1980s and research began to evaluate the utility of ORV for these wild canids ${ }^{136}$. By the mid-1990s, large-scale ORV began in west-central Texas for gray foxes and southern Texas for coyotes (Figure 2). To date, tens of millions of baits have been distributed in the state over tens of millions of square kilometers. The last case of coyote rabies virus variant was detected during 2004 and the last case of gray fox rabies virus variant was diagnosed during 2013 (in an infected cow) ${ }^{74}$. Gray fox vaccination has ceased, with the elimination of that rabies virus variant, but, as a precaution, annual ORV maintenance occurs in southern Texas because of the threat of the re-emergence of coyote rabies. In concept, ORV programs could be expanded, based upon enhanced surveillance, particularly within Mexico and border locations ${ }^{137}$. Around the globe, additional species and biologics are under evaluation for ORV application ${ }^{138-144}$. Moreover, given the success of ORV in rabies suppression, other diseases are also being explored for prevention and control in wildlife ${ }^{145-148}$. Operational studies in different taxa will continue to uncover

Table 5. Evidence of global progress in applied rabies prevention, control, and elimination.

\begin{tabular}{|c|c|c|c|}
\hline Locality & Interval & Item & Reference \\
\hline India & $2012-2016$ & $\begin{array}{l}\text { Gradual estimated declines in human rabies cases within seven states (primarily } \\
\text { because of human prophylaxis), with a need for improved surveillance at a national } \\
\text { level }\end{array}$ & 116 \\
\hline China & $2007-2017$ & $\begin{array}{l}\text { Decrease in estimated human cases from 3,300 to } 516 \text { (primarily because of } \\
\text { human prophylaxis) at a national level, based on passive surveillance }\end{array}$ & 117 \\
\hline Republic of Korea & 1998 to date & $\begin{array}{l}\text { Classified as a notifiable disease since 1961, with a decrease of } 68 \text { animal rabies } \\
\text { cases to } 0 \text { by 2014, primarily by domestic animal vaccination and oral vaccination } \\
\text { of wildlife }\end{array}$ & 118 \\
\hline Thailand & $1980-2015$ & $\begin{array}{l}\text { Human rabies cases decreased from } \sim 370 \text { to } \sim 5 \text {, concomitant with decline in } \\
\text { animal cases }\end{array}$ & 119 \\
\hline Vietnam & $1992-2017$ & Reduced human-reported deaths from 404 to 74 & 120 \\
\hline Sri Lanka & $1973-2015$ & $\begin{array}{l}\text { With a national plan for elimination, human deaths declined from } 377 \text { to } 24 \text {, while } \\
\text { dog vaccinations increased from }<300,000 \text { to }>1.4 \text { million }\end{array}$ & 121 \\
\hline $\begin{array}{l}\text { KwaZulu-Natal, South } \\
\text { Africa }\end{array}$ & $2007-2014$ & $\begin{array}{l}\text { Using a combination of methods, including increased public education, human } \\
\text { prophylaxis, and dog vaccination, canine cases fell from } 473 \text { to } 37 \text { and human } \\
\text { cases were reduced from approximately } 9 \text { to } 0\end{array}$ & 122 \\
\hline $\begin{array}{l}\text { Americas ( } 21 \text { Latin } \\
\text { American and } \\
\text { Caribbean countries) }\end{array}$ & $1998-2014$ & Consistent decline in human and canine rabies case incidence, approaching 0 & 123 \\
\hline Europe & $1978-2016$ & $\begin{array}{l}\text { Based upon the European rabies surveillance data base, only 3,982 total animal } \\
\text { cases were reported (an approximately 4.3-fold decrease) and at least } 12 \text { countries } \\
\text { self-declared rabies freedom, primarily because of oral vaccination of wildlife }\end{array}$ & 124 \\
\hline
\end{tabular}




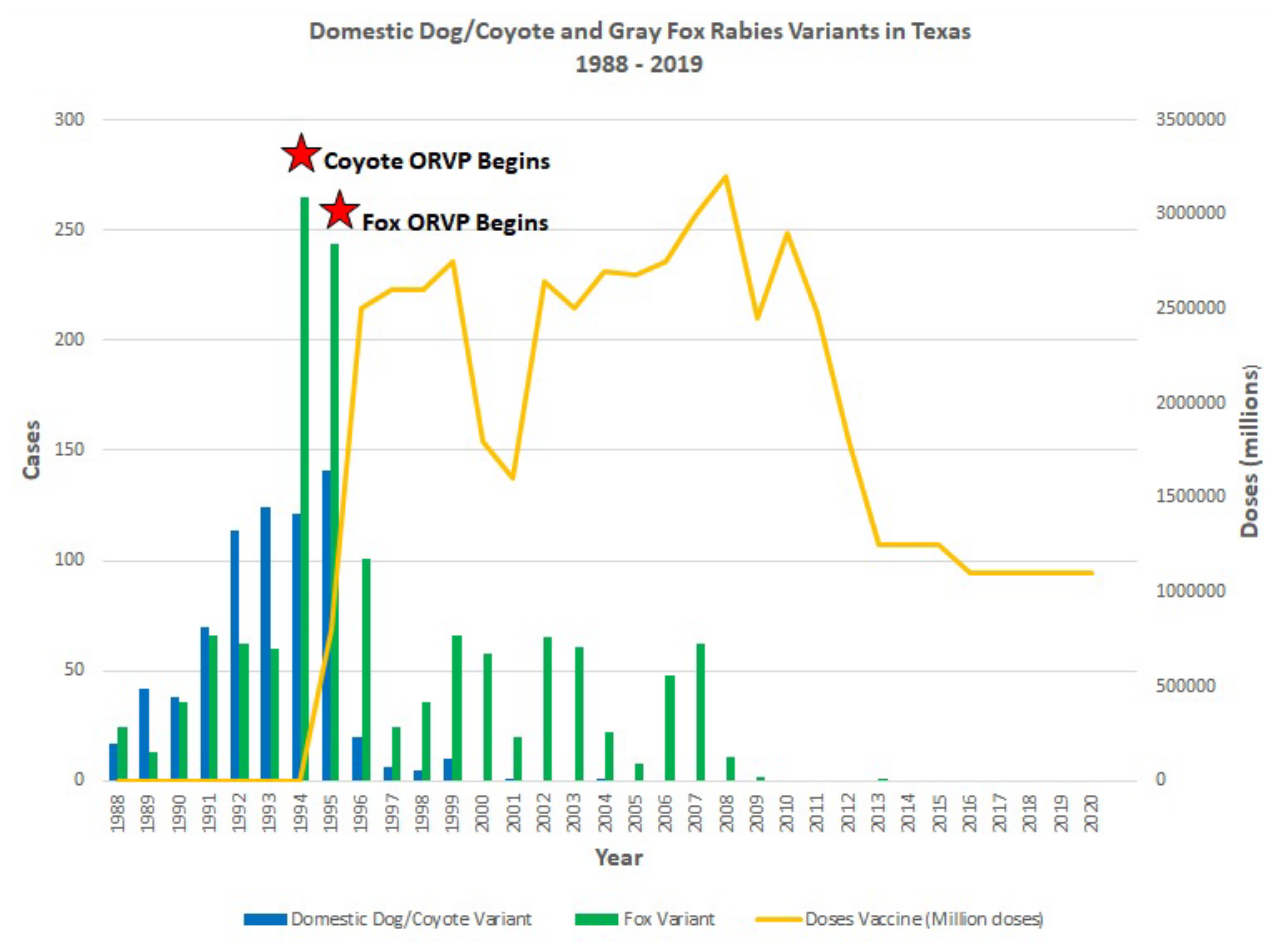

Figure 2. Demonstration of the impact of the Texas oral rabies vaccination program (ORVP) in response to coyote and gray fox rabies outbreaks. Comparison of laboratory-diagnosed cases of coyote and gray fox rabies virus variants to the combined number of oral rabies vaccine doses distributed over time in west-central and southern Texas, leading to elimination.

basic pathobiological and immunological mechanisms to improve upon the next generation of $\mathrm{ORV}^{149}$. Such advances stand as a legacy to those researchers from the 1960s who grappled with pragmatic ideas of how to approach the problem of wildlife reservoirs once canine rabies was prevented, controlled, or eliminated.

\section{Experimental treatment options}

In comparison to rabies vaccines and antibodies for humans, anti-viral strategies have also been under development, with renewed fervor post-2004 and documentation of the first survivor without a history of vaccination, yet with much less discernable clinical progress, in part because of the obstacle of safe and effective delivery of compounds to the central nervous system $^{55,150,151}$. Fundamentally, unlike the former focus on biologics, designed to prevent a productive infection, the latter efforts wrestle primarily with the "post-infection treatment" dilemma when routine public health interventions fail, and a clinical case develops. Recent investigations demonstrate that nucleoside inhibitors and their analogs, previously identified to inhibit other RNA viruses, are also capable of limiting lyssavirus replication. These could present potential broader-spectrum anti-viral candidates for future concentration. For example, a recent study demonstrated that favipiravir (T-705), a viral RNA-dependent RNA polymerase inhibitor that acts as a purine analog (shown previously to protect against filovirus infection), can limit lyssavirus infection in vitro ${ }^{16}$. Not surprisingly, observations of several such drug effects are not easily extrapolatable to in vivo data ${ }^{152,153}$. The likelihood of finding a lyssavirus-specific modality is predictably low, compared to the potential finesse of broader approaches for other "high-stakes" RNA virus targets among the Mononegavirales ${ }^{154}$. In the interim, this highly controversial aspect of the field will see-saw between an empirical, research-based in vitro/in vivo side and an emergency "hit-or-miss best guess" slant to clinical treatment of lyssavirus encephalitis, in which, among others, patient families, hospital administrators, multiple medical specialties, national regulators, ethicists, viral diagnosticians, and developers of novel biologics, as well as fit-for-purpose anti-viral drugs, will all play a part $2,42,55,150-155$. In addition, one part of the dilemma is the absence of relevant animal models to consider for actual clinical rabies treatment, particularly in a manner similar to the management of human encephalitis. However, there is no shortage of domestic animals that are euthanized after rabies virus exposure or the onset of compatible illness. Rather than euthanasia as the only current tool, perhaps these naturally occurring animal cases might be better utilized under more ideal circumstances. For example, as veterinarians receive PrEP, institutional intensive care facilities are available to isolate and sedate suspects safely, and academic teaching hospitals are renown for their biomedical research, greater progress in the field overall might ensue if the profession embarked upon the more routine clinical care and experimental treatment of rabid domestic animal patients, based upon current insights. 


\section{Remaining issues}

Given the palpable enthusiasm and actual progress generated by the GEHRD concept to date, candor and objectivity in the context of current pandemic events help to color expectations with the approach and passage of a ZBT world. What might this entail? As reflected in daily headlines, interconnected competing priorities will remain a reality, in contrast to "just rabies". These include recognizable emergent communicable viral diseases (e.g. COVID-19 and zoonoses due to henipaviruses, hemorrhagic filoviruses, etc.), longstanding agricultural concerns over high-value commodities (e.g. ASF, FMDV, H1N1, etc.), devastating natural calamities, particularly associated with climate change (e.g. drought, fire, floods, etc.), and strong differing expert opinions about the "best way" to spend limited global funds in LDCs $^{156}$. Even under ideal circumstances, a sustainable ZBT business plan remains elusive given wandering variables (i.e. the number of dogs at risk, the quantity of vaccine doses needed, the determination of producers to meet rising demands, the opportunity costs of local vs. regional sources of biologics, long-term sources of support, etc.), as do other unresolved topics ${ }^{1,157,194,195}$. Nevertheless, these are just anticipated nuances of a plan well in motion, and, as finer-grained program plans for GEHRD evolve, countries will grapple with these and other broader debates, such as a dependence upon external sources of modern biologics vs. a very clear need for self-sustainability (https://www. dawn.com/news/1526311/pakistan-to-become-self-sufficient-infour-antisera-by-june).

One way to envision the landscape post-ZBT may be ascertained in part by scenarios whence this goal has already been achieved locally, nationally, or regionally ${ }^{158}$. Within this forum, some may toy with the somewhat unimaginable concept of "eradication" (i.e. quite dependent upon flexible terminology but in stark contrast to the obviousness patterned by the definition as pertinent to smallpox and rinderpest). Concomitant with such freedom is the flaunting by others of long-standing rules related to vaccination and the improper movement of adopted animals from LDCs that, not surprisingly, introduce rabies to previously canine rabies-free territories ${ }^{159,160}$. Similarly, a primary focus upon the threat of canine rabies translocation is warranted from enzootic to "free" areas, but ignoring the reality of wildlife rabies altogether seems an object legend for appreciation and disaster, using the experience of Taiwan alone ${ }^{161}$. Canine rabies deserves to be at the forefront, while wildlife rabies remains lurking prominently in the background. Understandably, while reservoirs such as foxes, mongooses, raccoons, and skunks have been recognized historically for many decades to centuries, such is not the case for ferret badgers, non-human primates, or other potential candidate hosts, especially in localities where lyssavirus surveillance is much less than ideal ${ }^{162}$.

As may be obvious from a cursorial examination of the more specialized aspects of the inarguable progress in rabies diagnostics and biologics, there is a certain skewedness towards technical approaches in disease problem-solving, with much less of a focus on more anthropological, economic, political, or societal concerns for introspection ${ }^{163,195}$. Without the inclusion of these arenas beyond mere "lip service", transdisciplinary boundaries persist, preventing an ultimate understanding of why a given program may fail ${ }^{164}$. Additionally, "vaccine hesitancy" has crept even into the rabies field, both human and veterinary, despite an abundance of need, safety data, and epidemiological modeling (https://www.avma.org/javma-news/2020-03-01/vaccinehesitancy). Unplanned exclusionary practices by discipline can undermine otherwise sophisticated solutions to long-term disease control, prevention, and elimination, unless there is a concerted effort to appreciate bias, conflict, distrust, xenophobia, polarization, and related administrative, community, cultural, and religious concerns ${ }^{165}$. In some situations, suppression of actionable healthcare priorities may not only be ignored but intentionally suppressed $^{166}$. Besides public and political disparities, there are similar disconnects on continuing education needs and maintaining expertise among healthcare workers, veterinary staff, and often-overlooked wildlife professionals ${ }^{167,168}$. Also, the expressed routine needs of the applied user and the academic provider approach to trendy, fundable high-tech solutions does appear in need of remedy (as opposed to the simple, practical, available, and inexpensive, e.g. cell-phone technology, locally produced coolers to maintain the cold-chain, etc. $)^{169,188,196}$.

One expectation of collateral damage from an unrelenting supply of naïve, unsupported, and alternative "facts" about nearly everything during the new internet age arises in part from the coverage and communications about rabies survivors and the misuse of simple terms, such as "treatment". Clearly, rabies is a vaccine-preventable disease but is not treatable, per $\mathrm{se}^{54}$. One suggested downside may be a public misunderstanding of the ability to receive an outdated misnomer of "post-exposure treatment" after the onset of illness and thus being somewhat cavalier in reception to an accepted biomedical notion of prompt and proper PEP. While it is one thing having a true shortage in supply of biologics, living far from healthcare, or being poor in the pocket in the affordability of what should be otherwise provided for free as a life-saving intervention, it is yet quite another to be the receiver of exaggerated, misinterpreted, or false news about rabies. Similarly, a perceived long "event horizon" towards the recognition of an actual documented therapy coupled with the ongoing tragedy of human rabies that will continue for the foreseeable future underscore serious discussions over patient rights and individual options for euthanasia and a dignified death in the face of an obviously fatal outcome, unless more attractive alternatives beckon (https://timesofindia. indiatimes.com/india/can-rabies-patients-opt-for-euthanasia/ articleshow/73164110.cms?utm_source=contentofinterest $\&$ utm_medium=text\&utm_campaign=cppst).

\section{Conclusions and future directions}

Lyssaviruses seem to attract special concentration compared to other members in the Rhabdoviridae, not the least of which is because these agents possess a zoonotic risk associated with the highest case fatality rate documented for any infectious disease. Besides stealth by modulation of replication locally and within the nervous system, lyssavirus proteins can effectively interact with host innate immunity and disable the establishment of otherwise resilient anti-viral responses. A fundamental understanding of this basic host-pathogen relationship at both the 
molecular and the cellular levels in multiple species and elucidating how non-traditional laboratory hosts, such as bats, might efficiently modulate lyssavirus infection under natural circumstances represent exciting challenges for future research. Such insights may open new avenues in the development of novel biologics and anti-viral strategies. These studies should lead to human and animal clinical trials, allowing the generation of new licensed vaccines, antibodies, drugs, and delivery systems that are even more efficient in the prevention or treatment of lyssavirus infection. Enhanced laboratory-based surveillance is key for human prophylaxis, domestic animal vaccination, wildlife management, program monitoring, and border controls. Otherwise, viral phenotypic plasticity combined with the broad distribution of known and suspected wild reservoirs, especially among mesocarnivores and bats, together with the likelihood of spillover to domestic animals, particularly dogs, raise the strong probability of enzootic perpetuation, epizootic spread, and translocation to "rabies-free" areas.

Over the past 10 years, substantial progress has occurred on a global level regarding pathogen discovery, diagnostics, prophylaxis, and engagement of professionals in academia, government, industry, and international non-governmental organizations. Further success requires maintaining this transdisciplinary philosophy, with collaboration among virologists, immunologists, epidemiologists, veterinarians, physicians, producers, regulators, economists, and social scientists within an updated One Health approach in a common endeavor to better understand, communicate, detect, prevent, control, and eliminate lyssavirus infections in the next decade ${ }^{170-183}$ (Table 6). Supporting focus, enthusiasm, and momentum, based upon the evidence at hand, is critical but will not be simple, overly rapid, or inexpensive (https://www.who.int/neglected_diseases/news/ WHO-EB-commend-progress-against-NTDs-and-calls-roadmap-2021-2030/en/). These timely critical lessons learned about surveillance, diagnosis, and management, with best practices applied from one pathogen more than millennia-old in the making, should also be applicable to many of tomorrow's emerging zoonoses. In this regard, the ensuing pandemic of SARS-CoV-2 presents a much-told cautionary tale as to a legacy related not only to rabies but also to other neglected tropical diseases as well $\left(\right.$ Table 7) ${ }^{199,200}$.

Table 6. Predictive scenarios for the rabies field over the next decade.

\begin{tabular}{|l|l|}
\hline Likely events & $\begin{array}{l}\text { Supportive } \\
\text { citations }\end{array}$ \\
\hline Broadened surveillance for new lyssavirus species among bats and other mammals & 170 \\
\hline $\begin{array}{l}\text { Prediction and documentation of associated mammalian species reservoir status for } \\
\text { unresolved lyssaviruses (e.g. Mokola, Shimoni, etc.) }\end{array}$ & 171 \\
\hline Better appreciation of bat reservoirs in suggestive "rabies-free" areas, such as islands & 172 \\
\hline $\begin{array}{l}\text { Refinement of linear flow and related assays for improved "point of care" use in the rapid } \\
\text { diagnosis of lyssaviruses }\end{array}$ & 173 \\
\hline Movement beyond pilot projects towards actual national canine rabies elimination in Asia & 120 \\
\hline Demonstration of regional elimination of human rabies mediated via dogs in Africa & 174 \\
\hline Clinical trials of new biologics to reduce or replace the use of rabies immunoglobulins & 175 \\
\hline Expansion of human monoclonal antibodies breadth against divergent lyssaviruses & 176 \\
\hline $\begin{array}{l}\text { Licensing of purified, serum-free rabies vaccines, with updated label claims for } \\
\text { intradermal use }\end{array}$ & 177 \\
\hline Considerations on the use of oral rabies vaccines for other species, such as bats & 178 \\
\hline Use of a single vaccine dose for pre-exposure vaccination in remote communities at risk & 179 \\
\hline Abandonment of animal testing in the determination of vaccine potency & 180,198 \\
\hline Evidence in support of anti-viral drug use based upon insight to viral targets & 30 \\
\hline Programmatic use of oral vaccination of dogs for control among free-ranging animals & 181 \\
\hline $\begin{array}{l}\text { Elimination of canine rabies in Latin America and better "south-south" engagements for } \\
\text { repetition of best practices beyond technology }\end{array}$ & 182 \\
\hline "In situ genomic surveillance" expansion within lesser developed countries & 183 \\
\hline Protection of "free regions" by expansive elimination of canine rabies in enzootic areas & 184 \\
\hline Utilization of Gavi support for human rabies vaccination into national health programs & 185 \\
\hline
\end{tabular}


Table 7. Potential impacts of the COVID-19 pandemic upon rabies activities.

\begin{tabular}{|c|c|}
\hline Benefits & Limitations \\
\hline $\begin{array}{l}\text { Greater appreciation for diseases of nature and viral zoonoses } \\
\text { specifically, such as rabies }\end{array}$ & Lessons lost, due to pandemic fatigue \\
\hline Enhanced laboratory-based surveillance for lyssaviruses & $\begin{array}{l}\text { Pathogen discovery focused primarily upon } \\
\text { coronaviruses alone }\end{array}$ \\
\hline $\begin{array}{l}\text { Additional scrutiny to better understand how bat populations deal } \\
\text { with lyssavirus burden }\end{array}$ & $\begin{array}{l}\text { Unnecessary backlash against bat } \\
\text { populations in general }\end{array}$ \\
\hline $\begin{array}{l}\text { Broader consideration of dogs now as pets, rather than livestock } \\
\text { for consumption, closure of wildlife markets, and halting use of } \\
\text { bats as bushmeat }\end{array}$ & $\begin{array}{l}\text { Unpopular consumptive activities driven } \\
\text { ever more underground }\end{array}$ \\
\hline Shelter-in-place, limiting human exposure to rabid animals & $\begin{array}{l}\text { Mass unemployment drives even greater } \\
\text { community shifts and increases individual } \\
\text { movements for resources }\end{array}$ \\
\hline $\begin{array}{l}\text { More animals vaccinated in aftermath of best practices, including } \\
\text { use of drive-up clinics }\end{array}$ & $\begin{array}{l}\text { Veterinary services not viewed as an } \\
\text { essential activity compared to public health }\end{array}$ \\
\hline $\begin{array}{l}\text { New vaccine approaches provide insights for novel human } \\
\text { prophylaxis }\end{array}$ & $\begin{array}{l}\text { Unfulfilled promises and adverse events } \\
\text { sour demand for novel products }\end{array}$ \\
\hline $\begin{array}{l}\text { Anti-viral strategies reap extension against other RNA viruses, } \\
\text { such as in the Mononegavirales }\end{array}$ & No major cross-reactivity to rhabdoviruses \\
\hline Broader One Health adoptive strategies & $\begin{array}{l}\text { Anti-public health sentiments due to } \\
\text { presumption of civil liberties lost }\end{array}$ \\
\hline $\begin{array}{l}\text { Global elimination of human rabies mediated via dogs (GEHRD) } \\
\text { achieved before } 2030 \text { owing to greater preventive focus }\end{array}$ & $\begin{array}{l}\text { GEHRD setback for decades owing to } \\
\text { economic global repercussions }\end{array}$ \\
\hline
\end{tabular}

\section{Acknowledgements}

We thank Dr. Laura Robinson of the Texas Department of State Health Services, Zoonosis Control Division, for her kind assistance in supplying updated information on the oral rabies vaccination program for the creation of Figure 2.
Disclaimer

This article is the sole work product of the authors. The statements, opinions, or conclusions contained therein do not necessarily represent any agency or organization. The use of any commercial product names is for comparative purposes only and does not constitute endorsement by any of the authors, organizations, or agencies.
1. Rupprecht C, Kuzmin I, Meslin F: Lyssaviruses and rabies: current conundrums, concerns, contradictions and controversies [version 1; peer review: 2 approved]. F1000Res. 2017; 6: 184.

PubMed Abstract | Publisher Full Text | Free Full Text

2. World Health Organization: WHO Expert Consultation on Rabies. Third Report WHO TRS \#1012, Geneva, Switzerland, 2019; 183 Reference Source

3. Fooks AR: Conclusions Rabies. Rev Sci Tech. 2018; 37(2): 761-9. PubMed Abstract | Publisher Full Text

4. Shipley R, Wright E, Selden D, et al:: Bats and Viruses: Emergence of Novel Lyssaviruses and Association of Bats with Viral Zoonoses in the EU. Trop Med Infect Dis. 2019; 4(1): 31.

PubMed Abstract | Publisher Full Text | Free Full Text

5. Kotait I, Oliveira RdN, Carrieri ML, et al.: Non-human primates as a reservoir for rabies virus in Brazil. Zoonoses Public Health. 2019; 66(1): 47-59. PubMed Abstract | Publisher Full Text

6. Zhao JH, Zhao LF, Liu F, et al:: Ferret badger rabies in Zhejiang, Jiangxi and Taiwan, China. Arch Virol. 2019; 164(2): 579-84. PubMed Abstract | Publisher Full Text

7. World Health Organization: Laboratory techniques in rabies. 5th ed. WHO.
Geneva, Switzerland. 2019.

Reference Source

8. Yoder J, Younce E, Lankester F, et al:: Healthcare demand in response to rabies elimination campaigns in Latin America. PLoS Negl Trop Dis. 2019; 13(9): e0007630.

PubMed Abstract | Publisher Full Text | Free Full Text |

Faculty Opinions Recommendation

9. Abela-Ridder B, Balogh de K, Kessels JA, et al:: Global rabies control: The role of international organisations and the Global Strategic Plan to eliminate dogmediated human rabies. Rev Sci Tech. 2018; 37(2): 741-9.

PubMed Abstract | Publisher Full Text

10. Bharti OK, Thakur B, Rao R: Wound-only injection of rabies immunoglobulin (RIG) saves lives and costs less than a dollar per patient by "pooling strategy". Vaccine. 2019; 37 Suppl 1: A128-A131.

PubMed Abstract | Publisher Full Text

11. Sparrow E, Torvaldsen S, Newall AT, et al:: Recent advances in the development of monoclonal antibodies for rabies post exposure prophylaxis: A review of the current status of the clinical development pipeline. Vaccine. 2019; 37 Suppl 1: A132-A139.

PubMed Abstract | Publisher Full Text 
12. Warrell MJ: Simplification of Rabies Postexposure Prophylaxis: A New 2-Visit Intradermal Vaccine Regimen. Am J Trop Med Hyg. 2019; 101(6): 1199-201. PubMed Abstract | Publisher Full Text | Free Full Text

13. Botto Nuñez G, Becker DJ, Plowright RK: The emergence of vampire bat rabies in Uruguay within a historical context. Epidemiol Infect. 2019; 147: e180. PubMed Abstract | Publisher Full Text | Free Full Text

14. Kessels JA, Recuenco S, Navarro-Vela AM, et al.: Pre-exposure rabies prophylaxis: A systematic review. Bull World Health Organ. 2017; 95(3): 210-219C.

PubMed Abstract | Publisher Full Text | Free Full Text

15. Poston R, Hill R, Allen $\mathrm{C}$, et al:: Achieving scientific and regulatory success in implementing non-animal approaches to human and veterinary rabies vaccin testing: A NICEATM and IABS workshop report. Biologicals. 2019; 60: 8-14. PubMed Abstract | Publisher Full Text

16. Yamada K, Noguchi K, Kimitsuki K, et al.: Reevaluation of the efficacy of favipiravir against rabies virus using in vivo imaging analysis. Antiviral Res. 2019; 172: 104641

PubMed Abstract | Publisher Full Text | Faculty Opinions Recommendation

17. Cliquet F, Guiot AL, Aubert M, et al:: Oral vaccination of dogs: A well-studied and undervalued tool for achieving human and dog rabies elimination. Vet Res. 2018; 49(1): 61.

PubMed Abstract | Publisher Full Text | Free Full Text

18. Pan American Health Organization: Mexico is free from human rabies transmitted by dogs. Media Center, 2019

Reference Source

19. Hampson K, Ventura F, Steenson R, et al.: The potential effect of improved provision of rabies post-exposure prophylaxis in Gavi-eligible countries: A modelling study. Lancet Infect Dis. 2019; 19(1): 102-11. PubMed Abstract | Publisher Full Text | Free Full Text

20. Bertoune MAR, Nickl B, Krieger T, et al: The phenotype of the RABV glycoprotein determines cellular and global virus load in the brain and is decisive for the pace of the disease. Virology. 2017; 511: 82-94. PubMed Abstract | Publisher Full Text

21. Hossain MA, Larrous F, Rawlinson SM, et al:: Structural Elucidation of Viral Antagonism of Innate Immunity at the STAT1 Interface. Cell Rep. 2019; 29(7): 1934-1945.e8.

PubMed Abstract | Publisher Full Text | Faculty Opinions Recommendation

22. Zaeck L, Potratz M, Freuling CM, et al.: High-Resolution 3D Imaging of Rabies Virus Infection in Solvent-Cleared Brain Tissue. J Vis Exp. 2019; (146). PubMed Abstract | Publisher Full Text

23. Ogino M, Gupta N, Green TJ, et al:: A dual-functional priming-capping loop of rhabdoviral RNA polymerases directs terminal de novo initiation and capping intermediate formation. Nucleic Acids Res. 2019; 47(1): 299-309. PubMed Abstract | Publisher Full Text | Free Full Text

24. Riedel C, Vasishtan D, Pražák V, et al:: Cryo EM structure of the rabies virus ribonucleoprotein complex. Sci Rep. 2019; 9(1): 9639. PubMed Abstract | Publisher Full Text | Free Full Text

25. Zhang $Y$, Wang $Y$, Feng $Y$, et al:: Proteomic Profiling of Purified Rabies Virus Particles. Virol Sin. 2020; 35(2): 143-55. PubMed Abstract | Publisher Full Text | Free Full Text Faculty Opinions Recommendation

26. Jespersen NE, Leyrat C, Gérard FC, et al.: The LC8-RavP ensemble Structure Evinces A Role for LC8 in Regulating Lyssavirus Polymerase Functionality. J Mol Biol. 2019; 431: 4959-77.

PubMed Abstract | Publisher Full Text | Free Full Text

27. Luo J, Zhang Y, Zhang Q, et al.: The Deoptimization of Rabies Virus Matrix Protein Impacts Viral Transcription and Replication. Viruses. 2019; 12(1): 4 PubMed Abstract | Publisher Full Text | Free Full Text

28. Belot L, Albertini A, Gaudin Y: Structural and cellular biology of rhabdovirus entry. Adv Virus Res. 2019; 104: 147-83. PubMed Abstract | Publisher Full Text

29. Nikolic J, Lagaudrière-Gesbert $\mathrm{C}$, Scrima $\mathrm{N}$, et al:: Structure and Function of Negri Bodies. Adv Exp Med Biol. 2019; 1215: 111-27. PubMed Abstract | Publisher Full Text

30. Horwitz JA, Jenni S, Harrison SC, et al.: Structure of a rabies virus polymerase complex from electron cryo-microscopy. Proc Natl Acad Sci U S A. 2020; 117(4): 2099-107.

PubMed Abstract | Publisher Full Text | Free Full Text

31. Hellert J, Buchrieser J, Larrous F, et al:: Structure of the prefusion-locking broadly neutralizing antibody RVC20 bound to the rabies virus glycoprotein. Nat Commun. 2020; 11(1): 596.

PubMed Abstract | Publisher Full Text | Free Full Text

32. Yang F, Lin S, Ye F, et al:: Structural Analysis of Rabies Virus Glycoprotein Reveals pH-Dependent Conformational Changes and Interactions with a Neutralizing Antibody. Cell Host Microbe. 2020; 27(3): 441-453.e7. PubMed Abstract | Publisher Full Text

33. Davis BM, Rall GF, Schnell MJ: Everything You Always Wanted to Know About Rabies Virus (But Were Afraid to Ask). Annu Rev Virol. 2015; 2(1): 451-71. PubMed Abstract | Publisher Full Text | Free Full Text

34. Potratz M, Zaeck L, Christen M, et al:: Astrocyte Infection during Rabies Encephalitis Depends on the Virus Strain and Infection Route as
Demonstrated by Novel Quantitative 3D Analysis of Cell Tropism. Cells. 2020; 9(2): 412

PubMed Abstract | Publisher Full Text | Free Full Text |

Faculty Opinions Recommendation

35. Dietzschold B, Morimoto K, Hooper DC, et al:: Genotypic and phenotypic diversity of rabies virus variants involved in human rabies: Implications fo postexposure prophylaxis. J Hum Virol. 2000; 3(1): 50-7.

PubMed Abstract

36. Kammouni W, Wood H, Jackson AC: Lyssavirus phosphoproteins increase mitochondrial complex I activity and levels of reactive oxygen species. $J$ Neurovirol. 2017; 23(5): 756-62.

PubMed Abstract | Publisher Full Text

37. Sundaramoorthy V, Green D, Locke K, et al:: Novel role of SARM1 mediated axonal degeneration in the pathogenesis of rabies. PLoS Pathog. 2020; 16(2): e1008343.

PubMed Abstract | Publisher Full Text | Free Full Text |

Faculty Opinions Recommendation

38. Khalsi F, Ayari A, Romdhane MB, et al:: Rabies encephalitis in children: A resurgence of a fatal anthropozoonosis. Afr Health Sci. 2018; 18(3): 539-41. PubMed Abstract | Publisher Full Text | Free Full Text

39. Zhao H, Zhang J, Cheng C, et al:: Rabies Acquired through Mucosal Exposure, China, 2013. Emerging Infect Dis. 2019; 25(5): 1028-9.

PubMed Abstract | Publisher Full Text | Free Full Text

40. Lu XX, Zhu WY, Wu GZ: Rabies virus transmission via solid organs or tissue allotransplantation. Infect Dis Poverty. 2018; 7(1): 82 PubMed Abstract | Publisher Full Text | Free Full Tex

41. Ghosh S, Rana MS, Islam MK, et al.: Trends and clinico-epidemiological features of human rabies cases in Bangladesh 2006-2018. Sci Rep. 2020; 10(1): 2410.

PubMed Abstract | Publisher Full Text | Free Full Text |

Faculty Opinions Recommendation

42. Jackson AC: Rabies: A medical perspective. Rev Sci Tech. 2018; 37(2): 569-80. PubMed Abstract | Publisher Full Text

43. Farahtaj F, Alizadeh L, Gholami A, et al:: Natural Infection with Rabies Virus: A Histopathological and Immunohistochemical Study of Human Brains. Osong Public Health Res Perspect. 2019; 10(1): 6-11.

PubMed Abstract | Publisher Full Text | Free Full Text

44. Bokade CM, Gajimwar VS, Meshram RM, et al:: Survival of Atypical Rabies Encephalitis. Ann Indian Acad Neurol. 2019; 22(3): 319-21.

PubMed Abstract | Publisher Full Text | Free Full Text

45. Jackson AC, Del Bigio MR: Reader Response: Rabies encephalitis presenting with new-onset refractory status epilepticus (NORSE). Neurol Clin Pract. 2018; 8(5): 370-371.

PubMed Abstract | Publisher Full Text | Free Full Text

46. Luo Z, Li Y, Zhou M, et al.: Toll-Like Receptor 7 Enhances Rabies VirusInduced Humoral Immunity by Facilitating the Formation of Germinal Centers. Front Immunol. 2019; 10: 429.

PubMed Abstract | Publisher Full Text | Free Full Text |

Faculty Opinions Recommendation

47. Katz ISS, Guedes F, Fernandes ER, et al.: Immunological aspects of rabies: A literature review. Arch Virol. 2017; 162(11): 3251-68.

PubMed Abstract | Publisher Full Text

48. Li C, Zhang H, Ji L, et al:: Deficient Incorporation of Rabies Virus Glycoprotein into Virions Enhances Virus-Induced Immune Evasion and Viral Pathogenicity. Viruses. 2019; 11(3): 218.

PubMed Abstract | Publisher Full Text | Free Full Text | Faculty Opinions Recommendation

49. Gold $S$, Donnelly $C A$, Nouvellet $P$, et al: Rabies virus-neutralising antibodies in healthy, unvaccinated individuals: What do they mean for rabies epidemiology? PLoS Negl Trop Dis. 2020; 14(2): e0007933. PubMed Abstract | Publisher Full Text | Free Full Text

50. Ertl HCJ: Human immune responses to traditional and novel rabies vaccines. Rev Sci Tech. 2018; 37(2): 649-56.

PubMed Abstract | Publisher Full Text

51. Franka $R$, Wallace $R$ : Rabies diagnosis and surveillance in animals in the era of rabies elimination. Rev Sci Tech. 2018; 37(2): 359-70.

PubMed Abstract | Publisher Full Text

52. Dacheux L, Bourhy H: Diagnostic tests for human rabies. Rev Sci Tech. 2018 37(2): 581-93

PubMed Abstract | Publisher Full Text

53. Gourlaouen M, Angot A, Mancin M, et al:: An inter-laboratory trial as a tool to increase rabies diagnostic capabilities of Sub-Saharan African Veterinary laboratories. PLoS Negl Trop Dis. 2020; 14(2): e0008010. PubMed Abstract | Publisher Full Text | Free Full Text

54. Wilson, PJ, Rohde RE, Oertli EH, et al.: Rabies: Clinical Considerations and Exposure Evaluations. Elsevier Press, St. Louis, Missouri, USA. 2019. Reference Source

55. Smith SP, Wu G, Fooks AR, et al.: Trying to treat the untreatable: Experimenta approaches to clear rabies virus infection from the CNS. J Gen Virol. 2019; 100(8): 1171-86.

PubMed Abstract | Publisher Full Text 
56. Gigante CM, Dettinger L, Powell JW, et al.: Multi-site evaluation of the LN34 pan-lyssavirus real-time RT-PCR assay for post-mortem rabies diagnostics. PLoS One. 2018; 13(5): e0197074.

PubMed Abstract | Publisher Full Text | Free Full Text

Faculty Opinions Recommendation

57. Davis AJ, Nelson KM, Kirby JD, et al:: Rabies Surveillance Identifies Potential Risk Corridors and Enables Management Evaluation. Viruses. 2019; 11(11): 1006.

PubMed Abstract | Publisher Full Text | Free Full Text

58. Undurraga EA, Meltzer MI, Tran $\mathrm{CH}$, et al: Cost-Effectiveness Evaluation of a Novel Integrated Bite Case Management Program for the Control of Human Rabies, Haiti, 2014-2015. Am J Trop Med Hyg. 2017; 96(6): 1307-17. PubMed Abstract | Publisher Full Text | Free Full Text

59. Brunker K, Nadin-Davis S, Biek R: Genomic sequencing, evolution and molecular epidemiology of rabies virus. Rev Sci Tech. 2018; 37(2): 401-8. PubMed Abstract | Publisher Full Text

60. de Thoisy B, Bourhy H, Delaval M, et al.: Bioecological Drivers of Rabies Virus Circulation in a Neotropical Bat Community. PLoS Negl Trop Dis. 2016; 10(1): e0004378.

PubMed Abstract | Publisher Full Text | Free Full Text

61. de Rocha SM, Oliveira SV, Heinemann MB, et al.: Epidemiological Profile of Wild Rabies in Brazil (2002-2012). Transbound Emerg Dis. 2017; 64(2): 624-33. PubMed Abstract | Publisher Full Text

62. Huettmann F, Magnuson EE, Hueffer K: Ecological niche modeling of rabies in the changing Arctic of Alaska. Acta Vet Scand. 2017; 59(1): 18. PubMed Abstract | Publisher Full Text | Free Full Text

63. Nadin-Davis SA, Fehlner-Gardiner C, Gilbert AT: Origins of the arctic fox variant rabies viruses responsible for recent cases of the disease in southern Ontario. PLoS Negl Trop Dis. 2019; 13(9): e0007699.

PubMed Abstract | Publisher Full Text | Free Full Text |

Faculty Opinions Recommendation

64. Fisher CR, Streicker DG, Schnell MJ: The spread and evolution of rabies virus: Conquering new frontiers. Nat Rev Microbiol. 2018; 16(4): 241-55. PubMed Abstract | Publisher Full Text | Free Full Text

65. Hampson K, Coudeville L, Lembo T, et al:: Estimating the global burden of endemic canine rabies. PLoS Negl Trop Dis. 2015; 9(4): e0003709. PubMed Abstract | Publisher Full Text | Free Full Text

66. Rupprecht CE, Bannazadeh Baghi H, Del Rio Vilas VJ, et al.: Historical, current and expected future occurrence of rabies in enzootic regions. Rev Sci Tech. 2018; 37(2): 729-39.

PubMed Abstract | Publisher Full Tex

67. Harrist A, Styczynski A, Wynn D, et al:: Human Rabies - Wyoming and Utah, 2015. MMWR Morb Mortal Wkly Rep. 2016; 65(21): 529-33. PubMed Abstract | Publisher Full Text

68. Johnson N, Montano Hirose JA: The impact of paralytic bovine rabies transmitted by vampire bats in Latin America and the Caribbean. Rev Sci Tech. 2018; 37(2): 451-9.

PubMed Abstract | Publisher Full Text

69. Khismatullina NA, Gulyukin AM, Gulyukin MI, et al: [Two cases of hydrophobia in the Republic of Tatarstan: In vivo and postmortem laboratory diagnosis]. $\mathrm{Vopr}$ Virusol. 2015; 60(2): 18-24. PubMed Abstract

70. Taxitiemuer A, Tuerdi G, Zhang Y, et al:: An Investigation of the First Case of Human Rabies Caused by a Fox in China in May 2016. Biomed Environ Sci. 2017; 30(11): 825-8.

PubMed Abstract | Publisher Full Text

71. Yang DK, Kim HH, Lee KK, et al.: Mass vaccination has led to the elimination of rabies since 2014 in South Korea. Clin Exp Vaccine Res. 2017; 6(2): 111-9. PubMed Abstract | Publisher Full Text | Free Full Text

72. Huang J, Ruan S, Shu Y, et al:: Modeling the Transmission Dynamics of Rabies for Dog, Chinese Ferret Badger and Human Interactions in Zhejiang Province, China. Bull Math Biol. 2019; 81(4): 939-62.

PubMed Abstract | Publisher Full Text

73. Birhane MG, Cleaton JM, Monroe BP, et al:: Rabies surveillance in the United States during 2015. J Am Vet Med Assoc. 2017; 250(10): 1117-30. PubMed Abstract | Publisher Full Text

74. Ma X, Monroe BP, Cleaton JM, et al:: Public Veterinary Medicine: Public Health: Rabies surveillance in the United States during 2018. J Am Vet Med Assoc. 2020; 256(2): 195-208.

PubMed Abstract | Publisher Full Text | Faculty Opinions Recommendation

75. Styczynski A, Tran C, Dirlikov E, et al:: Human Rabies - Puerto Rico, 2015 MMWR Morb Mortal Wkly Rep. 2017; 65(52): 1474-6. PubMed Abstract | Publisher Full Text

76. Mani RS, Sundara Raju YG, Ramana PV, et al:: Human rabies following a nonhuman primate bite in India. J Travel Med. 2016; 23(3): taw007. PubMed Abstract | Publisher Full Text

77. Markotter W, Coertse J: Bat lyssaviruses. Rev Sci Tech. 2018; 37(2): 385-400. PubMed Abstract | Publisher Full Text

78. Marston DA, Banyard AC, McElhinney LM, et al.: The lyssavirus host-specificity conundrum-rabies virus-the exception not the rule. Curr Opin Virol. 2018; 28: 68-73.

PubMed Abstract | Publisher Full Text
79. Faria NR, Suchard MA, Rambaut A, et al:: Simultaneously reconstructing viral cross-species transmission history and identifying the underlying constraints. Philos Trans R Soc Lond B Biol Sci. 2013; 368(1614): 20120196.

PubMed Abstract | Publisher Full Text | Free Full Text

80. Nadin-Davis S, Alnabelseya N, Knowles MK: The phylogeography of Myotis bat-associated rabies viruses across Canada. PLOS Negl Trop Dis. 2017; 11(5): e0005541.

PubMed Abstract | Publisher Full Text | Free Full Text

81. Escobar LE, Peterson AT, Favi M, et al:: Bat-borne rabies in Latin America. Rev Inst Med Trop Sao Paulo. 2015; 57(1): 63-72.

PubMed Abstract | Publisher Full Text | Free Full Text

82. Kuzmina NA, Lemey $P$, Kuzmin IV, et al.: The phylogeography and spatiotemporal spread of south-central skunk rabies virus. PLOS One. 2013; 8(12): e82348.

PubMed Abstract | Publisher Full Text | Free Full Text

83. Ding NZ, Xu DS, Sun YY, et al:: A permanent host shift of rabies virus from Chiroptera to Carnivora associated with recombination. Sci Rep. 2017; 7(1): 289

PubMed Abstract | Publisher Full Text | Free Full Text

84. Troupin C, Dacheux L, Tanguy M, et al.: Large-Scale Phylogenomic Analysis Reveals the Complex Evolutionary History of Rabies Virus in Multiple Carnivore Hosts. PLoS Pathog. 2016; 12(12): e1006041. PubMed Abstract | Publisher Full Text | Free Full Text

85. Gilbert AT: Rabies virus vectors and reservoir species. Rev Sci Tech. 2018; 37(2): 371-84.

PubMed Abstract | Publisher Full Text

86. Hikufe $\mathrm{EH}$, Freuling $\mathrm{CM}$, Athingo R, et al.: Ecology and epidemiology of rabies in humans, domestic animals and wildlife in Namibia, 2011-2017. PLOS Negl Trop Dis. 2019; 13(4): e0007355

PubMed Abstract | Publisher Full Text | Free Full Text |

Faculty Opinions Recommendation

87. Vora NM, Orciari LA, Niezgoda M, et al:: Clinical management and humoral immune responses to rabies post-exposure prophylaxis among three patients who received solid organs from a donor with rabies. Transpl Infect Dis. 2015; 17(3): 389-95

PubMed Abstract | Publisher Full Text | Free Full Text

88. Brookes VJ, Dürr S, Ward MP: Rabies-induced behavioural changes are key to rabies persistence in dog populations: Investigation using a network-based model. PLoS Negl Trop Dis. 2019; 13(9): e0007739.

PubMed Abstract | Publisher Full Text | Free Full Text | Faculty Opinions Recommendation

89. Theimer TC, Dyer AC, Keeley BW, et al.: Ecological Potential for Rabies Virus Transmission via Scavenging of Dead Bats by Mesocarnivores. J Wildl Dis. 2017; 53(2): 382-5

PubMed Abstract | Publisher Full Tex

90. Lobo D, DeBenedet C, Fehlner-Gardiner C et al: Raccoon rabies outbreak in Hamilton, Ontario: A progress report. Can Commun Dis Rep. 2018; 44(5): 116-21.

PubMed Abstract | Publisher Full Text | Free Full Text

91. Pieracci EG, Pearson CM, Wallace RM, et al:: Vital Signs: Trends in Human Rabies Deaths and Exposures - United States, 1938-2018. MMWR Morb Mortal Wkly Rep. 2019; 68(23): 524-8. PubMed Abstract | Publisher Full Text | Free Full Text

92. Abedi M, Doosti-Irani A, Jahanbakhsh F, et al.: Epidemiology of animal bite in Iran during a 20-year period (1993-2013): A meta-analysis. Trop Med Health 2019; 47: 55.

PubMed Abstract | Publisher Full Text | Free Full Text |

Faculty Opinions Recommendation

93. Soler-Rangel S, Jiménez-Restrepo N, Nariño D, et al:: Rabies encephalitis and extra-neural manifestations in a patient bitten by a domestic cat. Rev Inst Med Trop Sao Paulo. 2020; 62: e1.

PubMed Abstract | Publisher Full Text | Free Full Text

94. Rocha F, Dias RA: The common vampire bat Desmodus rotundus (Chiroptera: Phyllostomidae) and the transmission of the rabies virus to livestock: A contact network approach and recommendations for surveillance and control. Prev Vet Med. 2020; 174: 104809.

PubMed Abstract | Publisher Full Text | Faculty Opinions Recommendation

95. Dato VM, Campagnolo ER, Long J, et al:: Systematic Review of Human Bat Rabies Virus Variant Cases: Evaluating Unprotected Physical Contact with Claws and Teeth in Support of Accurate Risk Assessments. PLoS One. 2016; 11(7): e0159443.

PubMed Abstract | Publisher Full Text | Free Full Text

96. Purwo Suseno $P$, Rysava $K$, Brum $E$, et al.: Lessons for rabies control and elimination programmes: A decade of One Health experience from Bali, Indonesia. Rev Sci Tech. 2019; 38(1): 213-224. PubMed Abstract | Publisher Full Text

97. Dellicour S, Troupin C, Jahanbakhsh F, et al.: Using phylogeographic approaches to analyse the dispersal history, velocity and direction of vira lineages - Application to rabies virus spread in Iran. Mol Ecol. 2019; 28(18) 4335-50.

PubMed Abstract | Publisher Full Text | Faculty Opinions Recommendation

98. Hampson K, Abela-Ridder B, Bharti O, et al:: Modelling to inform prophylaxis 
regimens to prevent human rabies. Vaccine. 2019; 37(Suppl 1): A166-A173. PubMed Abstract | Publisher Full Text

99. Johnstone-Robertson SP, Fleming PJS, Ward MP, et al:: Predicted Spatial Spread of Canine Rabies in Australia. PLoS Negl Trop Dis. 2017; 11(1): e0005312. PubMed Abstract | Publisher Full Text | Free Full Text

100. Bemis K, Frias M, Patel MT, et al.: Using an Emergency Department Syndromic Surveillance System to Evaluate Reporting of Potential Rabies Exposures, Illinois, 2013-2015. Public Health Rep. 2017; 132(1_suppl): 59S-64S. PubMed Abstract | Publisher Full Text | Free Full Text

101. Schildecker S, Millien M, Blanton JD, et al:: Dog Ecology and Barriers to Canine Rabies Control in the Republic of Haiti, 2014-2015. Transbound Emerg Dis. 2017; 64(5): 1433-42. PubMed Abstract | Publisher Full Text

102. Giannakopoulos A, Valiakos G, Papaspyropoulos K, et al:: Rabies outbreak in Greece during 2012-2014: Use of Geographical Information System for analysis, risk assessment and control. Epidemiol Infect. 2016; 144(14): 3068-79. PubMed Abstract | Publisher Full Text

103. Elser JL, Hatch BG, Taylor LH, et al.: Towards canine rabies elimination: Economic comparisons of three project sites. Transbound Emerg Dis. 2018; 65 : 135-45.

PubMed Abstract | Publisher Full Text

104. Hsu CH, Brown CM, Murphy JM, et al.: Perceptions and Practices of Mass Bat Exposure Events in the Setting of Rabies Among U.S. Public Health Agencies. Zoonoses Public Health. 2017; 64(2): 127-36. PubMed Abstract | Publisher Full Text | Free Full Text

105. Medley AM, Millien MF, Blanton JD, et al.: Retrospective Cohort Study to Assess the Risk of Rabies in Biting Dogs, 2013 2015, Republic of Haiti. Trop Med Infect Dis. 2017; 2(12): 14

PubMed Abstract | Publisher Full Text | Free Full Text

106. Hwang GS, Rizk E, Bui LN, et al:: Adherence to guideline recommendations for human rabies immune globulin patient selection, dosing, timing, and anatomical site of administration in rabies postexposure prophylaxis. Hum Vaccin Immunother. 2020; 16(1): 51-60. PubMed Abstract | Publisher Full Text | Free Full Text Faculty Opinions Recommendation

107. Gebru G, Romha G, Asefa A, et al:: Risk Factors and Spatio-Temporal Patterns of Human Rabies Exposure in Northwestern Tigray, Ethiopia. Ann Glob Health 2019; 85(1): 119

PubMed Abstract | Publisher Full Text | Free Full Text

108. Mbilo C, Kabongo JB, Pyana PP, et al: Dog Ecology, Bite Incidence, and Disease Awareness: A Cross-Sectional Survey among a Rabies-Affected Community in the Democratic Republic of the Congo. Vaccines (Basel). 2019; 7(3): 98. PubMed Abstract | Publisher Full Text | Free Full Text

109. Mani RS, Damodar T, Divyashree S, et al: Case Reports: Survival from Rabies: Case Series from India. Am J Trop Med Hyg. 2019; 100(1): 165-9. PubMed Abstract | Publisher Full Text | Free Full Text

110. Peterson D, Barbeau B, McCaffrey K, et al:: Human Rabies - Utah, 2018. MMWR Morb Mortal Wkly Rep. 2020; 69(5): 121-4 PubMed Abstract | Publisher Full Text | Free Full Text

111. Manning SE, Rupprecht CE, Fishbein D, et al.: Human rabies prevention--United States, 2008: Recommendations of the Advisory Committee on Immunization Practices. MMWR Recomm Rep. 2008; 57(RR-3): 1-28. PubMed Abstract

112. Brown CM, Slavinski S, Ettestad P, et al.: Compendium of Animal Rabies Prevention and Control, 2016. J Am Vet Med Assoc. 2016; 248(5): 505-17. PubMed Abstract | Publisher Full Text

113. Banyard AC, McElhinney LM, Johnson $\mathrm{N}$, et al:: History of rabies control by vaccination. Rev Sci Tech. 2018; 37(2): 305-22. PubMed Abstract | Publisher Full Text

114. Pattanaik A, Mani RS: WHO's new rabies recommendations: Implication for high incidence countries. Curr Opin Infect Dis. 2019; 32(5): 401-406. PubMed Abstract | Publisher Full Text | Faculty Opinions Recommendation

115. O' Leary ST, Maldonado YA, Kimberlin DW: Update from the Advisory Committee on Immunization Practices. J Pediatric Infect Dis Soc. 2019; 8(6): 495-500. PubMed Abstract | Publisher Full Text

116. Sudarshan MK, Ashwath Narayana DH: Appraisal of surveillance of human rabies and animal bites in seven states of India. Indian J Public Health. 2019; 63(Supplement): S3-S8. PubMed Abstract | Publisher Full Tex

117. Qian MB, Chen J, Bergquist R, et al:: Neglected tropical diseases in the People's Republic of China: Progress towards elimination. Infect Dis Poverty. 2019; 8(1): 86 .

PubMed Abstract | Publisher Full Text | Free Full Text

118. Yang DK, Cho IS, Kim HH: Strategies for controlling dog-mediated human rabies in Asia: Using ' One Health' principles to assess control programmes for rabies. Rev Sci Tech. 2018; 37(2): 473-481. PubMed Abstract | Publisher Full Text

119. World Health Organization: Towards a rabies-free Thailand by 2020. Media reporting. Geneva, Switzerland. 2017. Reference Source

120. Nguyen HTT, Nguyen HT, Nguyen TTT, et al.: Progress towards rabies contro and elimination in Vietnam. Rev Sci Tech. 2019; 38(1): 199-212. PubMed Abstract | Publisher Full Text

121. Rahman SA, Isloor S: Rabies on the Indian subcontinent. Rev Sci Tech. 2018; 37(2): 529-42.

PubMed Abstract | Publisher Full Text

122. LeRoux K, Stewart D, Perrett KD, et al.: Rabies control in KwaZulu-Natal, South Africa. Bull World Health Organ. 2018; 96(5): 360-5. PubMed Abstract | Publisher Full Text | Free Full Text

123. Freire de Carvalho M, Vigilato MAN, Pompei JA, et al:: Rabies in the Americas: 1998-2014. PLoS Negl Trop Dis. 2018; 12(3): e0006271. PubMed Abstract | Publisher Full Text | Free Full Text

124. Müller FT, Freuling CM: Rabies control in Europe: An overview of past, current and future strategies. Rev Sci Tech. 2018; 37(2): 409-19. PubMed Abstract | Publisher Full Text

125. Cleaveland S, Thumbi SM, Sambo M, et al:: Proof of concept of mass dog vaccination for the control and elimination of canine rabies. Rev Sci Tech 2018; 37(2): 559-68.

PubMed Abstract | Publisher Full Text

126. Rattanavipapong W, Thavorncharoensap M, Youngkong S, et al.: The impact of transmission dynamics of rabies control: Systematic review. Vaccine. 2019; 37 Suppl 1: A154-A165.

PubMed Abstract | Publisher Full Text | Faculty Opinions Recommendation

127. Leung T, Davis SA: Rabies Vaccination Targets for Stray Dog Populations. Front Vet Sci. 2017; 4: 52. PubMed Abstract | Publisher Full Text | Free Full Text

128. J Jeon S, Cleaton J, Meltzer MI, et al.: Determining the post-elimination level of vaccination needed to prevent re-establishment of dog rabies. PLOS Negl Trop Dis. 2019; 13(12): e0007869.

PubMed Abstract | Publisher Full Text | Free Full Text | Faculty Opinions Recommendation

129. Mähl $\mathrm{P}$, Cliquet $\mathrm{F}$, Guiot $\mathrm{AL}$, et al:: Twenty year experience of the oral rabies vaccine SAG2 in wildlife: A global review. Vet Res. 2014; 45(1): 1 . PubMed Abstract | Publisher Full Text | Free Full Text

130. Cliquet F, Picard-Meyer E, Mojzis M, et al:: In-Depth Characterization of Live Vaccines Used in Europe for Oral Rabies Vaccination of Wildlife. PLOS One. 2015; 10(10): e0141537.

PubMed Abstract | Publisher Full Text | Free Full Text

131. Maki J, Guiot AL, Aubert M, et al.: Oral vaccination of wildlife using a vacciniarabies-glycoprotein recombinant virus vaccine (RABORAL V-RG ®): a global review. Vet Res. 2017; 48(1): 662 PubMed Abstract | Publisher Full Text | Free Full Text

132. Yang DK, Kim HH, Cho IS: Strategies to maintain Korea's animal rabies nonoccurrence status. Clin Exp Vaccine Res. 2018; 7(2): 87-92. PubMed Abstract | Publisher Full Text | Free Full Text

133. Head JR, Vos A, Blanton J, et al.: Environmental distribution of certain modified live-virus vaccines with a high safety profile presents a low-risk, high-reward to control zoonotic diseases. Sci Rep. 2019; 9(1): 6783. PubMed Abstract | Publisher Full Text | Free Full Text

134. Fehlner-Gardiner C: Rabies control in North America - past, present and future. Rev Sci Tech. 2018; 37(2): 421-37. PubMed Abstract | Publisher Full Tex

135. Elmore SA, Chipman RB, Slate D, et al.: Management and modeling approaches for controlling raccoon rabies: The road to elimination. PLOS Negl Trop Dis. 2017; 11(3): e0005249.

PubMed Abstract | Publisher Full Text | Free Full Text

136. Sidwa TJ, Wilson PJ, Moore GM, et al:: Evaluation of oral rabies vaccination programs for control of rabies epizootics in coyotes and gray foxes: 1995-2003. $J$ Am Vet Med Assoc. 2005; 227(5): 785-92. PubMed Abstract | Publisher Full Text

137. Garcés-Ayala F, Aréchiga-Ceballos N, Ortiz-Alcántara JM, et al: Molecula characterization of atypical antigenic variants of canine rabies virus reveals its reintroduction by wildlife vectors in southeastern Mexico. Arch Virol. 2017; 162(12): 3629-37. PubMed Abstract | Publisher Full Text

138. Hsu AP, Tseng $\mathrm{CH}$, Barrat $\mathrm{J}$, et al.: Safety, efficacy and immunogenicity evaluation of the SAG2 oral rabies vaccine in Formosan ferret badgers. PLoS One. 2017; 12(10): e0184831. PubMed Abstract | Publisher Full Text | Free Full Text

139. Zhugunissov $\mathrm{K}$, Bulatov $\mathrm{Y}$, Taranov $\mathrm{D}$, et al:: Protective immune response of oral rabies vaccine in stray dogs, corsacs and steppe wolves after a single immunization. Arch Virol. 2017; 162(11): 3363-70. PubMed Abstract | Publisher Full Text

140. Hassel R, Vos A, Clausen $P$, et al.: Experimental screening studies on rabies virus transmission and oral rabies vaccination of the Greater Kudu (Tragelaphus strepsiceros). Sci Rep. 2018; 8(1): 16599 PubMed Abstract | Publisher Full Text | Free Full Text

141. Ortmann S, Kretzschmar A, Kaiser C, et al.: In Vivo Safety Studies With SPBN GASGAS in the Frame of Oral Vaccination of Foxes and Raccoon Dogs Against Rabies. Front Vet Sci. 2018; 5: 91 PubMed Abstract | Publisher Full Text | Free Full Tex

142. Wohlers $\mathrm{A}$, Lankau EW, Oertli $\mathrm{EH}$, et al: Challenges to controlling rabies in 
skunk populations using oral rabies vaccination: A review. Zoonoses Public Health. 2018; 65(4): 373-85.

PubMed Abstract | Publisher Full Text

143. N Koeppel KN, Kuhn BF, Thompson PN: Oral bait preferences for rabies vaccination in free-ranging black-backed jackal (Canis mesomelas) and nontarget species in a multi-site field study in a peri-urban protected area in South Africa. Prev Vet Med. 2020; 175: 104867.

PubMed Abstract | Publisher Full Text | Faculty Opinions Recommendation

144. C Berentsen AR, Ellis CK, Johnson SR, et al:: Immunogenicity of Ontario Rabies Vaccine for Small Indian Mongooses (Herpestes auropunctatus). J Wildl Dis. 2020; 56(1): 224-228.

PubMed Abstract | Faculty Opinions Recommendation

145. Rossi S, Staubach C, Blome S, et al.: Controlling of CSFV in European wild boar using oral vaccination: A review. Front Microbiol. 2015; 6: 1141 PubMed Abstract | Publisher Full Text | Free Full Text

146. Kern A, Zhou CW, Jia F, et al:: Live-vaccinia virus encapsulation in pH-sensitive polymer increases safety of a reservoir-targeted Lyme disease vaccine by targeting gastrointestinal release. Vaccine. 2016; 34(38): 4507-13. PubMed Abstract | Publisher Full Text | Free Full Text

147. Lesellier S, Boschiroli ML, Barrat J, et al:: Detection of live M. bovis BCG in tissues and IFN- $\gamma$ responses in European badgers (Meles meles) vaccinated by oropharyngeal instillation or directly in the ileum. BMC Vet Res. 2019; 15(1): 445

PubMed Abstract | Publisher Full Text | Free Full Text Faculty Opinions Recommendation

148. Flies AS, Flies EJ, Fox S, et al:: An oral bait vaccination approach for the Tasmanian devil facial tumor diseases. Expert Rev Vaccines. 2020; 19(1): 1-10. PubMed Abstract | Publisher Full Text

149. N Te Kamp V, Freuling CM, Vos A, et al.: Responsiveness of various reservoi species to oral rabies vaccination correlates with differences in vaccine uptake of mucosa associated lymphoid tissues. Sci Rep. 2020; 10(1): 2919. PubMed Abstract | Publisher Full Text | Free Full Text | Faculty Opinions Recommendation

150. Koraka $P$, Martina $B$ : Antivirals for human use against rabies and prospects for their future application. Rev Sci Tech. 2018; 37(2): 673-80. PubMed Abstract | Publisher Full Text

151. Du Pont V, Plemper RK, Schnell MJ: Status of antiviral therapeutics against rabies virus and related emerging lyssaviruses. Curr Opin Virol. 2019; 35: 1-13. PubMed Abstract | Publisher Full Text | Free Full Text

152. Anindita PD, Sasaki M, Okada K, et al:: Ribavirin-related compounds exert in vitro inhibitory effects toward rabies virus. Antiviral Res. 2018; 154: 1-9. PubMed Abstract | Publisher Full Text

153. Rogée $\mathrm{S}$, Larrous $\mathrm{F}$, Jochmans $\mathrm{D}$, et al.: Pyrimethamine inhibits rabies virus replication in vitro. Antiviral Res. 2019; 161: 1-9. PubMed Abstract | Publisher Full Text

154. Latorre V, Mattenberger F, Geller R: Chaperoning the Mononegavirales: Curren Knowledge and Future Directions. Viruses. 2018; 10(12): 699. PubMed Abstract | Publisher Full Text | Free Full Text

155. Willoughby RE Jr: Rabies: Rare Human Infection - Common Questions. Infect Dis Clin North Am. 2015; 29(4): 637-50. PubMed Abstract | Publisher Full Text

156. Malarski M, Hasso-Agopsowicz M, Soble A, et al.: Vaccine impact on antimicrobial resistance to inform Gavi, the Vaccine Alliance's 2018 Vaccine Investment Strategy: report from an expert survey [version 1; peer review: 2 approved]. F1000Res. 2019; 8: 1685. PubMed Abstract | Publisher Full Text | Free Full Text Faculty Opinions Recommendation

157. Wallace RM, Undurraga EA, Blanton JD, et al:: Elimination of Dog-Mediated Human Rabies Deaths by 2030: Needs Assessment and Alternatives for Progress Based on Dog Vaccination. Front Vet Sci. 2017; 4: 9. PubMed Abstract | Publisher Full Text | Free Full Text

158. Robardet E, Bosnjak D, Englund L, et al:: Zero Endemic Cases of Wildlife Rabies (Classical Rabies Virus, RABV) in the European Union by 2020: An Achievable Goal. Trop Med Infect Dis. 2019; 4(4): 124. PubMed Abstract | Publisher Full Text | Free Full Text

159. Hercules $\mathrm{Y}$, Bryant $\mathrm{NJ}$, Wallace RM, et al:: Rabies in a Dog Imported from Egypt - Connecticut, 2017. MMWR Morb Mortal Wkly Rep. 2018; 67(50): 1388-91. PubMed Abstract | Publisher Full Text | Free Full Text

160. Cliquet F, Wasniewski M: Maintenance of rabies-free areas. Rev Sci Tech. 2018; 37(2): 691-702. PubMed Abstract | Publisher Full Text

161. Lan YC, Wen TH, Chang CC, et al.: Indigenous Wildlife Rabies in Taiwan: Ferret Badgers, a Long Term Terrestrial Reservoir. Biomed Res Int. 2017; 2017: 5491640.

PubMed Abstract | Publisher Full Text | Free Full Text

162. Coertse J, Markotter W, Le Roux K, et al:: New isolations of the rabies-related Mokola virus from South Africa. BMC Vet Res. 2017; 13(1): 37. PubMed Abstract | Publisher Full Text | Free Full Text

163. Bardosh KL: Towards a science of global health delivery: A socioanthropological framework to improve the effectiveness of neglected tropical disease interventions. PLoS Negl Trop Dis. 2018; 12(7): e0006537. PubMed Abstract | Publisher Full Text | Free Full Text

164. Attema $\mathrm{AE}, \mathrm{He} \mathrm{L}, \mathrm{Cook} A J C$, et al:: Unbiased assessment of disease surveillance utilities: A prospect theory application. PLoS Negl Trop Dis. 2019; 13(15): e0007364

PubMed Abstract | Publisher Full Text | Free Full Text

165. Aenishaenslin $C$, Brunet $P$, Lévesque $F$, et al.: Understanding the Connections Between Dogs, Health and Inuit Through a Mixed-Methods Study. EcoHealth. 2019; 16(1): 151-60 PubMed Abstract | Publisher Full Tex

166. Briggs $\mathrm{CL}$ : Uncovering a tragic flaw in revolutionary health policies: From health and communicative inequities to communicative justice in health. Salud Colect. 2017; 13(3): 411-27. PubMed Abstract | Publisher Full Text

167. Tarrant S, Grewal J, Yaglom H, et al.: Zoonotic Disease Exposure Risk and Rabies Vaccination Among Wildlife Professionals. EcoHealth. 2020; 17(1): 74-83.

PubMed Abstract | Publisher Full Text | Free Full Text |

Faculty Opinions Recommendation

168. Manoharan A, Chellaiyan VG, Madhusudan M: Effect of educational intervention on the knowledge of rabies among medical school students of Chennai. J Educ Health Promot. 2019; 8: 208.

PubMed Abstract | Publisher Full Text | Free Full Text

169. Neevel AMG, Hemrika T, Claassen E, et al:: A research agenda to reinforce rabies control: A qualitative and quantitative prioritization. PLOS Negl Trop Dis. 2018; 12(5): e0006387.

PubMed Abstract | Publisher Full Text | Free Full Text

170. Hsu WC, Hsu CL, Tu YC, et al.: Standard Operating Procedure for Lyssavirus Surveillance of the Bat Population in Taiwan. J Vis Exp. 2019; (150) PubMed Abstract | Publisher Full Text

171. Babayan SA, Orton RJ, Streicker DG: Predicting reservoir hosts and arthropod vectors from evolutionary signatures in RNA virus genomes. Science. 2018; 362(6414): $577-80$

PubMed Abstract | Publisher Full Text | Free Full Text

172. Seetahal JFR, Greenberg L, Satheshkumar PS, et al:: The Serological Prevalence of Rabies Virus-Neutralizing Antibodies in the Bat Population on the Caribbean Island of Trinidad. Viruses. 2020; 12(2):178. PubMed Abstract | Publisher Full Text | Free Full Text

173. Klein A, Fahrion A, Finke S, et al.: Further Evidence of Inadequate Quality in Lateral Flow Devices Commercially Offered for the Diagnosis of Rabies. Trop Med Infect Dis. 2020; 5(1): 13

PubMed Abstract | Publisher Full Text | Free Full Text

174. Athingo R, Tenzin T, Shilongo A, et al.: Fighting Dog-Mediated Rabies in Namibia - Implementation of a Rabies Elimination Program in the Northern Communal Areas. Trop Med Infect Dis. 2020; 5(1): 12. PubMed Abstract | Publisher Full Text | Free Full Text

175. Plummer JR, McGettigan JP: Incorporating B cell activating factor (BAFF) into the membrane of rabies virus (RABV) particles improves the speed and magnitude of vaccine-induced antibody responses. PLoS Negl Trop Dis. 2019; 13(11): e0007800.

PubMed Abstract | Publisher Full Text | Free Full Text

176. N de Benedictis P, Minola A, Rota Nodari E, et al:: Development of broadspectrum human monoclonal antibodies for rabies post-exposure prophylaxis. EMBO Mol Med. 2016; 8(4): 407-21.

PubMed Abstract | Publisher Full Text | Free Full Text |

Faculty Opinions Recommendation

177. Angsuwatcharakon $\mathrm{P}$, Khomvilai S, Limsuwun K, et al:: Immunogenicity and safety of WHO-approved TRC-ID regimen with a chromatographically purified Vero cell rabies vaccine with or without rabies immunoglobulin in children. Expert Rev Vaccines. 2018; 17(2): 185-188.

PubMed Abstract | Publisher Full Text

178. Bakker KM, Rocke TE, Osorio JE, et al:: Fluorescent biomarkers demonstrate prospects for spreadable vaccines to control disease transmission in wild bats. Nat Ecol Evol. 2019; 3(12): 1697-704.

PubMed Abstract | Publisher Full Text | Free Full Text

179. Wang C, Dulal $P$, Zhou $X$, et al.: A simian-adenovirus-vectored rabies vaccine suitable for thermostabilisation and clinical development for low-cost singledose pre-exposure prophylaxis. PLOS Negl Trop Dis. 2018; 12(10): e0006870. PubMed Abstract | Publisher Full Text | Free Full Text

180. Toinon A, Moreno N, Chausse $\mathrm{H}$, et al:: Potency test to discriminate between differentially over-inactivated rabies vaccines: Agreement between the NIH assay and a G-protein based ELISA. Biologicals. 2019; 60: 49-54. PubMed Abstract | Publisher Full Text

181. Gibson AD, Mazeri S, Yale G et al: Development of a Non-Meat-Based, Mass Producible and Effective Bait for Oral Vaccination of Dogs against Rabies in Goa State, India. Trop Med Infect Dis. 2019; 4(3): 118. PubMed Abstract | Publisher Full Text | Free Full Text

182. Vigilato MAN, Molina-Flores B, Del Rio Vilas VJ, et al:: Canine rabies elimination: Governance principles. Rev Sci Tech. 2018; 37(2): 703-709. PubMed Abstract | Publisher Full Text

183. Arunker K, Jaswant G, Thumbi SM, et al:: Rapid in-country sequencing of 
whole virus genomes to inform rabies elimination programmes [version 2; peer review: 3 approved]. Wellcome Open Res. 2020; 5: 3. PubMed Abstract | Publisher Full Text | Free Full Text | Faculty Opinions Recommendation

184. Rupprecht $C E$, Abela-Ridder $B, A b i l a ~ R$, et al.: Towards rabies elimination in the Asia-Pacific region: From theory to practice. Biologicals. 2020; 64: 83-95. PubMed Abstract | Publisher Full Text

185. Sudarshan MK: Vision 2030: Dog-mediated human rabies-free India: Action must begin now. Indian J Public Health. 2017; 61(1): 1-2. PubMed Abstract | Publisher Full Text

186. Tian B, Zhou M, Yang Y, et al.: Lab-Attenuated Rabies Virus Causes Abortive Infection and Induces Cytokine Expression in Astrocytes by Activating Mitochondrial Antiviral-Signaling Protein Signaling Pathway. Front Immunol. 2018; 8: 2011

PubMed Abstract | Publisher Full Text | Free Full Text

187. P Pattabhi S, Knoll ML, Gale M, et al:: DHX15 Is a Coreceptor for RLR Signaling That Promotes Antiviral Defense Against RNA Virus Infection. $J$ Interferon Cytokine Res. 2019; 39(6): 331-46. PubMed Abstract | Publisher Full Text | Free Full Text | Faculty Opinions Recommendation

188. Cleaton JM, Wallace RM, Crowdis K, et al.: Impact of community-delivered SMS alerts on dog-owner participation during a mass rabies vaccination campaign, Haiti 2017. Vaccine. 2018; 36(17): 2321-2325. PubMed Abstract | Publisher Full Text | Free Full Text

189. Salin P, Blondel D, Kerkerian-Le Goff L, et al.: Golgi staining-like retrograde labeling of brain circuits using rabies virus: Focus onto the striatonigral neurons. J Neurosci Methods. 2020; 344: 108872. PubMed Abstract | Publisher Full Text

190. John B, Kumar S, Kumar S, et al:: Child survivor of rabies in India: a case report. Paediatr Int Child Health. 2020; 1-6. PubMed Abstract | Publisher Full Text

191. Whitehouse ER, Peterson D, McCaffrey K, et al.: Evaluation of Online Risk Assessment To Identify Rabies Exposures Among Health Care Workers - Utah, 2019. MMWR Morb Mortal Wkly Rep. 2020; 69(29): 956-959. PubMed Abstract | Publisher Full Text | Free Full Text

192. Napolitano $F$, Merone $R$, Abbate $A$, et al.: A next generation vaccine against human rabies based on a single dose of a chimpanzee adenovirus vector serotype C. PLoS Negl Trop Dis. 2020; 14(7): e0008459. PubMed Abstract | Publisher Full Text | Free Full Text

193. Fisher CR, Lowe DE, Smith TG, et al.: Lyssavirus Vaccine with a Chimeric Glycoprotein Protects across Phylogroups. Cell Rep. 2020; 32(3): 107920. PubMed Abstract | Publisher Full Text | Free Full Text

194. Mbilo C, Coetzer A, Bonfoh B, et al:: Dog rabies control in West and Central Africa: A review. Acta Trop. 2020; 105459. PubMed Abstract | Publisher Full Text

195. Castillo-Neyra R, Buttenheim AM, Brown J, et al.: Behavioral and structural barriers to accessing human post-exposure prophylaxis and other preventive practices in Arequipa, Peru, during a canine rabies epidemic. PLoS Negl Trop Dis. 2020; 14(7): e0008478. PubMed Abstract | Publisher Full Text | Free Full Text

196. Lugelo A, Hampson K, Bigambo M, et al.: Controlling Human Rabies: The Development of an Effective, Inexpensive and Locally Made Passive Cooling Device for Storing Thermotolerant Animal Rabies Vaccines. Trop Med Infect Dis. 2020; 5(3): E130. PubMed Abstract | Publisher Full Text

197. Botto Nuñez G, Becker DJ, Lawrence RL, et al:: Synergistic Effects of Grassland Fragmentation and Temperature on Bovine Rabies Emergence. Ecohealth. 2020; 17(2): 203-216. PubMed Abstract | Publisher Full Tex

198. Sanchez N, Soulet D, Bonnet E, et al: Rabies Vaccine Characterization by Nanoparticle Tracking Analysis. Sci Rep. 2020; 10(1): 8149. PubMed Abstract | Publisher Full Text | Free Full Text

199. Nachega JB, Mbala-Kingebeni $\mathrm{P}$, Otshudiema J, et al.: Responding to the Challenge of the Dual COVID-19 and Ebola Epidemics in the Democratic Republic of Congo-Priorities for Achieving Control. Am J Trop Med Hyg. 2020; 103(2): 597-602 PubMed Abstract | Publisher Full Text | Free Full Text

200. Raynor B, Díaz EW, Shinnick J, et al:: The impact of the COVID-19 pandemic on rabies reemergence in Latin America: the case of Arequipa, Peru. Preprint. medRxiv. 2020; 2020.08.06.20169581. PubMed Abstract | Publisher Full Text | Free Full Text

201. Jackson AC, Fenton MB: Human rabies and bat bites. Lancet. 2001; 357(9269): 1714. PubMed Abstract | Publisher Full Text 